This is the post-print version of the following article:

Grappi S., Romani S., Bagozzi R. P. (in press, available online 22 November 2017). Reshoring from a demand-side perspective: Consumer reshoring sentiment and its market effects. Journal of World Business. https://doi.org/10.1016/j.jwb.2017.11.001

The final publication is available at: https://www.sciencedirect.com/science/article/pii/S1090951617302006

\title{
Reshoring from a demand-side perspective: Consumer Reshoring Sentiment and its market effects
}

\begin{abstract}
Reshoring is the company decision to relocate activities back to the home country. Our study complements the existing research in IB by adopting a demand-side perspective. We identify new, demand-based drivers for reshoring that integrate with the firm-based ones, thereby further informing the company decision process in this context. We develop a Consumer Reshoring Sentiment (CRS) scale through multiple studies conducted on consumers (total=1,149) in two countries. Our findings reveal: six demand-based drivers that compose CRS; a link between CRS and consumer willingness to reward the reshoring company; and the effectiveness of CRS in segmenting and targeting the market.
\end{abstract}

Keywords: reshoring, location strategy, consumer sentiment, measurement and scale development, market segmentation 


\section{INTRODUCTION}

Our study aims to analyze an emerging and increasingly important phenomenon, namely, company decisions to relocate activities back to the home country. We conceive of reshoring as a voluntary decision on the part of a company to relocate its activities back to the home country after having implemented an offshoring decision in the past, regardless of the ownership of the activities reshored (Ellram, 2013; Gray, Skowronski, Esenduran, \& Rungtusanatham, 2013). Our work complements the existing research in international business (IB) on reshoring by analyzing the phenomenon from a demand-side perspective (Priem, Li, \& Carr, 2012; Siqueira, Priem, \& Parente, 2015), arguing that the home country's demand characteristics can play a role in explaining company reshoring decisions. Thus, we aim to contribute to IB research by adding a new element to the existing knowledge base about the drivers for reshoring, namely, Consumer Reshoring Sentiment (CRS). CRS collects generalized, positive beliefs that home-country consumers associate with reshoring, and which companies should consider when the decision to relocate activities is evaluated. To this end, we look outside the company-towards its actual and potential end users (i.e., consumers)-to analyze the reshoring phenomenon. From this point of view, reshoring is examined as a way to increase the value created within a company's value system by emphasizing value-creation for consumers.

Reshoring practices are quite recent and relatively understudied to date, so that their scope and functions, for instance, are still largely unknown. Reshoring usually concerns international companies that decide to return to their highly developed countries of origin. The relevance of reshoring is steadily increasing (Sirkin, Zinser, Hohner, \& Rose, 2012), but more research is required to ascertain the full consequences of such a decision (Gray et al., 2013; Tate, Ellram, Petersen, \& Schoenherr, 2014a). Despite the difficulty of obtaining public data (Gray et al., 2013), recent empirical research has begun to describe reshoring. Kinkel and colleagues (Kinkel \& Maloca, 2009; Kinkel, 2012; Kinkel \& Zanker, 2013) found that reshoring has been a concern in about $25 \%$ of the German companies sampled. Dachs and Kinkel (2013) analyzed reshoring in eight European countries, revealing marked differences in the amount of reshoring. Researchers recently developed a specific data base consisting of 294 reshoring operations based on secondary data (Fratocchi, Nassimbeni, Zanoni, Ancarani, Valente, Sartor, Barbieri, DiMauro, \& Vignoli, 2011; Fratocchi, 
Barbieri, DiMauro, Nassimbeni, \& Vignoli, 2013; Fratocchi, Di Mauro, Barbieri, Nassimbeni, \& Zanoni, 2014). The predominant countries in the data base are the U.S., Germany, and Italy, suggesting that reshoring is clearly more common in some countries than others.

Current literature on reshoring has mainly focused on the definition of the phenomenon (Ellram, 2013; Fratocchi et al., 2014; Gray et al., 2013) and its geographical boundaries, including, for example, the identification of the host countries most involved (Dachs \& Kinkel, 2013). Specific attention has also been given to the drivers for a company's reshoring decision and, to this end, Transaction Cost Theory (TCT) (Williamson, 2008), the Resource-Based View (RBV) (Teece, Pisano, \& Shuen, 1997), internalization theory (Buckley \& Casson, 1976; 2011), and Dunning's “eclectic paradigm" (Dunning, 1980, 1998) have been widely applied (Fratocchi, Ancarani, Barbieri, Di Mauro, Nassimbeni, Sartor, Vignoli, \& Zanoni, 2016). Adopting the firm-side perspective, several studies (e.g., Canham \& Hamilton; Casson, 2013; Dachs \& Kinkel, 2013; Dachs \& Zanker, 2015; Ellram, Tate, \& Petersen, 2013; Fratocchi et al. , 2016; Gray et al. 2013; Kinkel \& Maloca, 2009; Kinkel \& Zanker, 2013; Kinkel, 2012; 2014; Kinkel \& Maloca, 2009; Martínez-Mora \& Merino, 2014; Nujen, Halse, \& Solli-Sæther, 2015; Wu \& Zhang, 2014) have identified important firm-based drivers underlying reshoring, shedding unique light on the company decision-making process. This important progress notwithstanding, a demand-side perspective also can be critical to company value creation: companies must pay attention to consumer demand in strategic decision-making (e.g., Priem et al., 2012). For example, Grappi, Romani, and Bagozzi (2015) reveal some preliminary results on positive beliefs consumers have about this major strategic decision. This notwithstanding, much remains to be learned about whether, and to what extent, demand factors can bring new elements into the company decision process that are useful and measurable (i.e., demand-based drivers for reshoring). Extending this demand-side perspective to the reshoring context, we argue that reshoring decisions can be driven in part by the home country's local demand characteristics.

To this end, we explore the relevant, generalized, long-term positive beliefs that consumers hold about reshoring. These beliefs are part of an overall appraisal structure that we conceptually and empirically investigate under the label of Consumer Reshoring Sentiment (CRS). CRS collects new, demand-side drivers that companies should consider, together with the firm-side drivers identified in 
previous IB research, when they evaluate reshoring. Taking into consideration CRS, a company will be able to examine and assess, through the reliable and validated measurement scale developed in this paper, the extent to which reshoring can increase consumers' perceived value of its offerings, and thus the extent to which reshoring can expand the overall consumer value created by the company. By including demand-side considerations, we help deepen and extend our current understanding of the reshoring decision-making process and provide new empirical evidence on the demand-side perspective. The empirical work that examines the impact of home country local demand on a company's reshoring decision is sparse. Our paper is among the first we know to examine demandside predictions in the reshoring context, thereby complementing the existing IB research on reshoring (for similar contributions in different IB contexts, see Bailey \& Li, 2015 and Krause, Filatotchev, \& Bruton, 2016).

The remainder of the paper is structured as follows: 1) we present a review of the literature to identify how reshoring is currently studied in the IB field. 2) We then present a preliminary qualitative study aimed at analyzing reshoring from the demand-side perspective, identifying key consumer beliefs associated with reshoring. The findings become the starting point from which we develop the CRS construct and its measures. 3) Then follows the development process of a reliable and valid measurement scale of CRS (the CRS scale). Based on our proposed conceptualization, a series of complementary studies on Italian consumers is carried out to validate a psychometrically sound scale, which is further tested on American consumers to strengthen its generalizability and practical applicability. In fact, as this theme can be sensitive to the social and political climate of one country, we developed the CRS scale by focusing on one specific country (Italy) and subsequently tested its characteristics by applying it in a different country (the U.S.), reinforcing its ecological validity. 4) Differential market reactions depending on CRS are then identified. We reveal positive links between CRS and consumers' market responses to reshoring (i.e. attitudes towards companies that reshore, positive word of mouth, and intentions to buy the reshoring company's products), thereby confirming the ability of reshoring to increase value created within the company's value system. 5) Finally, we show the effectiveness of CRS in segmenting and targeting home country markets. Following a crosscountry validation of the CRS scale, we present an empirical application showing the effectiveness of 
CRS in segmenting home country consumers, together with another relevant dimension (i.e., ethnocentrism) that is related to, but different from, reshoring sentiment. In short, by adding the demand-side perspective on reshoring to that of the firm-side, we raise consumer issues to the strategic level, adding complexities that have the potential to enrich IB research in new and original ways.

\section{THE RESHORING PHENOMENON}

\subsection{Theoretical framework}

Based on the principal theoretical perspectives used in studying reshoring (i.e., TCT, RBV, internalization theory, and Dunning's "eclectic paradigm") current research delineates the decisionmaking process of the company as primarily guided by the following drivers for reshoring. Advantages of costs (i.e., cost-based drivers for reshoring) are identified by current research as pivotal factors for decisions to reshore activities from abroad. Cost considerations favoring reshoring can derive from corrections of a previous miscalculation of the actual costs of offshoring (Gray et al. 2013; Kinkel \& Maloca, 2009), or from a deliberate decision related to exogenous changes (e.g., labor cost gap reduction, Kinkel and Zanker, 2013; Kinkel, 2012; 2014; increased home country productivity, Nujen et al.,, 2015) or endogenous changes (e.g., increased coordination costs, Dachs \& Kinkel, 2013; Dachs \& Zanker, 2015; Kinkel \& Maloca, 2009). Using a macro-level perspective, other studies found that reconfiguration decisions, including reshoring, can be also favored by changes in the global economy (e.g., cost and risk-related factors that affect location characteristics, Casson, 2013) or by governance choices (e.g., changes in the competitive model that lead to changes in the supply chain structure, Martínez-Mora \& Merino, 2014). Reshoring has also been studied adopting a multi-dimensional view, not focused primarily on how to lower unit costs but on how to obtain unique sets of resources and competences able to give a sustainable competitive advantage to the company (i.e., resource-based drivers for reshoring). Strategic resources and capabilities are considered crucial drivers for the company's location decisions (Barney, 1991). In this perspective, reshoring decisions reflect the company's efforts in developing critical assets by moving activities back to the home country (e.g. to ensure a higher level of production quality, Ancarani DiMauro, Fratocchi, Orzes, \& Sartor, 2015; Canham \& Hamilton, 2013; to get access to materials, 
infrastructure, local talent, and/or suppliers, Ellram et al. 2013; to improve the relationship with distributors, Martínez-Mora \& Merino, 2014; to ensure a higher level of flexibility so as to avoid problems associated with market size shrinking and volatility; Wu \& Zhang, 2014).

All these studies shed a unique light on the company decision-making process in terms of relocating activities back to the home country, but they explain the phenomenon as mainly stemming from negative performance assessments of the previous offshoring decision (Fratocchi et al., 2014; Kinkel \& Maloca, 2009; Kinkel, 2012). Albertoni, Elia, Massini, and Piscitello (2017), by applying the disintegration, location-specific, and externalization (DLE) framework (Kedia \& Mukherjee, 2009) for studying reshoring of business services, found that reshoring can be explained not only as a result of a company's response to performance shortcomings of offshoring, but also as a company decision motivated by persisting with original offshoring decision (disintegration advantages, accessing new markets, and cost-saving), regardless of offshoring performance.

Despite the numerous and important findings provided by the existing research mentioned above, these studies largely neglect the demand-side factors that may also help to further our understanding. It is this lack of attention to demand-side factors that provides the motivation for our research. Currently, we know very little about whether demand factors affect and complement the existing literature on reshoring and, if they do, to what extent they can usefully integrate new elements into the company decision process (i.e. demand-based drivers for reshoring). Thus in this research we seek to overcome these shortcomings by 1) identifying consumer positive beliefs about reshoring that we conceptually develop and empirically investigate under the label of consumer reshoring sentiment (CRS), 2) examining the effects of these drivers on favoring positive responses to the home-country market (e.g. increasing intentions to buy the reshoring company's products), and 3) showing the effectiveness of using these demand-factor drivers in segmenting and properly targeting home-country markets. In this perspective, CRS collects new, demand-side drivers that companies can consider, together with the firm-side drivers identified in previous research, when evaluating reshoring.

\subsection{Consumer reshoring sentiment}


In line with the basic psychological literature (e.g., Shand, 1922; Arnold, 1969; Frijda \& Mesquita, 2000), we define consumer reshoring sentiment as an appraisal structure that includes relevant, generalized, long-term positive beliefs associated by the consumer with reshoring. Such sentiment consists of the consumers' latent representations of the reshoring phenomenon as being relevant to their concerns, suggesting also what kinds of action might be desirable towards companies that undertake this decision. In other words, CRS includes significant consumer reshoring beliefs relevant to one's various concerns, such as those pertaining to personal welfare (e.g. the perceived higher quality of the reshored products) or the welfare of others (e.g. higher employment rates in the home country). In our research, CRS is scrutinized by considering the reshoring company's homecountry market. The focus is on consumers in developed countries, since reshoring is a new and growing phenomenon that mainly concerns companies that return to highly developed home-countries following efforts at offshoring in lesser developed countries.

In order to identify relevant, positive beliefs associated by the consumer with reshoring, we first conducted a qualitative study based on in-depth interviews with actual consumers. Beliefs identified in the study were then organized based on their nature and characteristics. This resulted in six principal and distinct dimensions, as detailed below.

\subsection{Qualitative study}

Our qualitative study was designed to increase our understanding of the composition and structure of consumer multiple beliefs about reshoring. In this way, a comprehensive schema is revealed of relevant consumer positive beliefs related to (and underlying) consumer sentiment toward reshoring. These beliefs are important because they are thought to undergird consumer behavioral responses to company reshoring decisions. This preliminary study also helped us in developing the measurement scale for constructs, suggesting items consistent with the specific words and idioms actually used by consumers. Table 1 details the research methodology followed.

---Table 1 about here ---

Common themes in participants' narratives were identified and discussed by researchers using procedures suggested by Spiggle (1994) which presents a framework composed of different stages for qualitative data analysis and interpretation. The theme most commonly reported and discussed by 
participants in the qualitative study was the "superior quality of reshored production". The majority of respondents expressed thoughts and opinions on this topic, highlighting higher perceived quality and the related issue of the safety of reshored products. These considerations are usually associated with positive feelings and intentions to act favorably towards companies that decided to reshore. The main elements listed by interviewees referred to the greater transparency in the relocated processes of production, resulting in perceived higher quality standards compared to those obtained abroad.

Another theme discussed very frequently by participants during the interviews was about the "made-in effect". Many respondents reported the importance of such an effect in their product evaluations and discussed the inextricable connection between this element and the companies' location decision. The reshoring decisions were seen not only as a means for supporting and strengthening Italian manufacturing, but also as a way to preserve the "made-in-Italy" productions. The feelings associated with this concern were positive and generally connected to the sense of pride in being an Italian.

"Competency availability" is the third theme that emerged in the analysis. The competencies and skills of home-country workers were frequently discussed by participants who, with regard to many products, reported characteristics connected with the believed superior abilities of Italian workers compared to those of foreign workers. Participants generally appreciated a company's decision to reshore because they saw in this an acknowledgement of the superior skills of Italian workers and consequently they believe that this can have positive effects on the production.

Another theme discussed by participants was "government support". Interviewees reported comments and considerations regarding the role that the government, together with its policy institutions, should play; participants strongly believed that it should support and encourage company reshoring decisions. These respondents often said they would be ready to support economic incentives, such as tax reductions or subsidies, to encourage companies to reshore. Thus, consumer beliefs indicated that the governments of developed countries should do more to favor companies "coming back home" with their activities in order to increase the economic wellbeing of the home country. 
Judgments about the "greater ability to fulfill needs" of reshored products also emerged as a distinct reaction. Interviewees believed that products made abroad, especially in emerging countries, are less able to satisfy their needs compared to those made in the home countries. In general, most participants believed that reshored products are superior to offshored ones in satisfying their needs.

Finally, a specific theme summarizing concerns connected to "ethical issues in host countries" arose. Some of the interviewees emphasized that reshoring can be viewed as an ethical company decision because it ensures not only a greater compliance with the law (e.g. reshoring in a developed country often leads to greater environmental conformance and compliance with pollution restriction rules, compared to the case of offshoring in developing countries), but also greater attention to moral and ethical values in general. Recent ethical scandals involving such big-named brands as Nike (its supply chain accused of labor abuses in developing countries) or Apple (suicides at Foxconn's factories where its iPhones are produced) were reported as examples that lead interviewees to perceive offshoring as an unethical company decision. By contrast, they consider reshoring as an ethical decision of companies that choose to give up possible (unethical) benefits offered by offshoring in emerging countries. The ethical beliefs reported by participants were, for example, that they welcome reshoring because these decisions are seen to stop the exploitation of foreign workers, environmental pollution, and human rights infringement in foreign emerging countries.

These six themes that emerged from the interviews, summarizing consumer beliefs towards reshoring, will guide the generation of measurement items and form the underlying dimensions of the consumer reshoring sentiment construct, as developed below. It is worth noting here that some beliefs that consumers hold clearly refer to reasons for reshoring considered by companies in their decision processes (e.g., production quality). Consumers and companies tend to appraise the reshoring phenomenon on similar dimensions but in a completely different perspective: the advantages for the company in a firm-side perspective versus the direct or indirect advantages for consumers in a demand-side perspective. Table 2 details the main results of the qualitative study and provides definitions for each dimension. At the same time, the table relates the dimensions to previous research that addresses similar topics through the firm-side perspective. 
---Table 2 about here ---

\section{SCALE DEVELOPMENT}

To empirically ground and deepen our understanding of the construct of CRS, we develop and validate a psychometrically sound multi-dimensional measurement scale. See Table 1 for an overview of the different studies we conducted, where the aim, the research methodology, and the sampling procedures followed in each study are presented.

\subsection{Development and Review of the initial pool of items}

A set of candidate items covering the meaning of CRS was generated following the qualitative study. An initial pool of 41 items was so created. Subsequently, three independent judgesall scholars highly experienced in management and marketing-reviewed and helped in reducing the pool of items to 34, after being provided with our definition of CRS. We asked judges to evaluate each item with respect to its relevance for the construct domain (Netemeyer, Bearden, \& Sharma, 2003) and to suggest any additional items to cover the construct domain of content widely (DeVellis, 2003). This process resulted in (a) the elimination of 10 items that two or more judges evaluated as not fully representing the dimension or excessively redundant, and (b) the addition of 3 new items. The revised pool of 34 items was administered to 5 actual, adult consumers to pre-test it for clarity and comprehensiveness. Results showed the presence of 7 items judged as not clear, ambiguous, difficult to understand, or redundant. These items were then dropped to improve content and face validity (Nunnally \& Bernstein, 1994), leading to a pool of 27 content-valid items subsequently subjected to quantitative scale purification methods, as detailed in the following sections.

\subsection{Study 1: Item Refinement}

The aim of Study 1 was to refine the initial pool of item (see Table 1 for details on research methodology, sampling procedure, and sample characteristics). An exploratory factor analysis (EFA) was performed on responses to items. The items were subjected to maximum likelihood exploratory factor analysis with oblique rotation (promax). Only items with factor loadings greater than 0.50 on their focal dimensions and not higher than 0.25 on other factors were retained. Six different factors $(\chi 2(72)=166.18 ; \mathrm{p}<0.001)$ were identified containing 19 items in total, which were then used in the subsequent analyses. The Cronbach alphas of the measures of the six dimensions were high, ranging 
from 0.89 to 0.92 . The six factors accounted for $77.6 \%$ of total variance and each factor explained at least 5\% of total variance, indicating strong factors (Hair, Black, Babin, Anderson, \& Tatham, 2005; Netemeyer et al., 2003).

\subsection{Study 2: Assessment of Scale Validity}

Study 2 was conducted to assess the scale dimensionality and to verify the discriminant validity of the CRS measures. See Table 1 for details on research methodology and sampling procedures followed in this study, as well as on sample characteristics.

\subsubsection{Scale dimensionality assessment.}

A six factor confirmatory factor analysis (CFA) was run on the items using LISREL 8.8 (Jöreskog \& Sörbom, 1996). Following a stepwise procedure to purify the measurement scale (Gerbing \& Anderson, 1988), one item (government support \#1) was deleted given substantial crossloadings on different dimensions than the focal one. Then, the 18 remaining items were used to run a new CFA (see Table 3). The model exhibited a satisfactory goodness-of-fit (Hu \& Bentler, 1999): $\chi^{2}$ $(\mathrm{df})=373.86(120) ; \mathrm{p}=0.00 ; \mathrm{CFI}=0.96 ; \mathrm{NNFI}=0.96 ; \mathrm{RMSEA}=0.09 ; \mathrm{SRMR}=0.06$. Scale composite reliability always exceeded the cut-off level of 0.70 , and variance extracted exceeded 0.50 for each of the six dimensions (Hair et al., 2005). All standardized item-to-factor loadings exceeded 0.70 (Hair et al., 2005) demonstrating adequate convergent validity (see Table 3 ). The shared variance between factors was less than the average variance extracted for any pair, and the levels of the AVE for each construct are greater than the squared correlation involving the constructs (Fornell \& Larcker, 1981), indicating that the items measure distinct constructs (Churchill \& Iacobucci, 2002). These results show sound reliability and consistent structure for the 18-item CRS scale. The mean scores and standard deviations of each dimension are detailed in Table 3.

---Table 3 about here ---

Subsequently, a second-order factor model was tested. We introduced a second-order factor to collect the six specific first-order dimensions of CRS under one higher-order representation. The goodness-of-fit measures of the second-order factor model were satisfactory $\left(\chi^{2}(\mathrm{df})=406.02(129)\right.$; $\mathrm{p}$ $=0.00 ; \mathrm{CFI}=0.96 ; \mathrm{NNFI}=0.95 ; \mathrm{RMSEA}=0.09 ; \mathrm{SRMR}=0.07)$, demonstrating that the first-order factors can be represented in a more parsimonious way at a higher level of abstraction. The target 
coefficient between the first-order and the second-order models $\left(\mathrm{TC}=\chi^{2}\right.$ of the baseline model $/ \chi^{2}$ of the alternative model) (Marsh \& Hocevar, 1985) was above the recommended threshold of 0.90 (i.e., $\mathrm{TC}=(373.86 / 406.02)=0.92)$ showing the superiority of the second-order model in representing the data. Table 4 shows the parameter estimates of the completely standardized solution.

$$
\text { ---Table } 4 \text { about here --- }
$$

\subsubsection{Discriminant validity.}

To understand how beliefs comprising the CRS develop, it is also important to distinguish the CRS scale from other seemingly related concepts, that is, consumer ethnocentrism (CE) (Shimp \& Sharma, 1987) and patriotism (Balabanis, Diamantopoulos, Mueller, \& Melewar, 2001). These two variables are selected for the theoretical contiguity with the construct under study (i.e., CRS) ${ }^{1}$ and for

\footnotetext{
${ }^{1} \mathrm{CE}$ is defined as "the beliefs held by consumers about the appropriateness, indeed morality, of purchasing foreign made products" (Shimp \& Sharma, 1987: 280), encompassing issues such as one's fear of economically harming one's country by buying foreign products, the morality of buying imported products, and a personal prejudice against imports (Sharma, Shimp, \& Shin, 1995; Shimp \& Sharma, 1987). In other words, CE explains why consumers prefer domestic over imported products (Herche, 1992). CE differs from CRS with respect to nationally produced products and their purchase. Ethnocentric consumers consider buying national products as part of their duty to their country to protect its economy and support domestic producers, and thus it is a traitlike characteristic of consumers (Zeugner-Roth, Zabkar, \& Diamantopoulos, 2015), whereas CRS places emphasis on the advantages of buying national products (e.g., greater ability to fulfil one's needs) without any hostility toward foreign production, per se. CRS is the result of an evaluation process with respect to specific national products. By contrast, $\mathrm{CE}$ is essentially rooted in a predisposition or prejudice against other countries and their products; CRS is focused on benefits and positive returns of relocating company production back to the home country. On the other hand, patriotism refers to strong feelings of attachment and loyalty to one's own country without necessarily expressing hostility towards other nations (Balabanis et al., 2001; Kosterman \& Feshbach, 1989). Patriots, in general, exhibit a willingness to sacrifice for their country and subordinate their personal interests to national interests (Feshbach, 1990). All this often translates into a strong orientation toward domestic products (Han, 1988). Patriotism varies as a function of characteristics of consumers. CRS varies as a
} 
the role they may play in explaining consumer reactions to company location decisions (e.g., Grappi et al. 2015). Both ethnocentrism and patriotism are shown to favor strong orientations toward domestic products (e.g., Han, 1988; Herche, 1992), thus it is important to underline the specificities of the CRS construct with respect to these two related constructs. To show discriminant validity between measures of CRS, CE, and Patriotism, the 17-items of the CET-scale (Shimp \& Sharma, 1987) and 12 items to measure patriotism (Kosterman \& Feshbach 1989) were included in the study. All the comparisons tests between CRS and, respectively, CE and Patriotism, were detailed in Appendix C. Results indicate that the CRS scale measures distinct and independent constructs compared to consumer ethnocentrism and patriotism.

\subsection{Study 3: Multitrait-Multimethod Analysis}

A multitrait-multimethod (MTMM) matrix analysis was performed using LISREL 8.8 (Jöreskog \& Sörbom, 1996) to confirm the validity of our measures (e.g., Bagozzi, 2011; Bagozzi \& Edwards, 1998; Bagozzi, Yi, \& Philips, 1991). Table 1 details the research methodology and sampling procedures followed in this study, along with the sample characteristics. The CFA model of the MTMM matrix fit adequately: $\chi 2(\mathrm{df})=195.22(28), \mathrm{p}=0.00 ; \mathrm{CFI}=0.94 \mathrm{NNFI}=0.90 ; \mathrm{RMSEA}=$ $0.11 ; \mathrm{SRMR}=0.07$. This model was compared to the trait-only model $(\Delta \chi 2(\Delta \mathrm{df}=11)=218.41, \mathrm{p}<$ $0.01)$ and the method-only model $(\Delta \chi 2(\Delta \mathrm{df}=25)=777.42, \mathrm{p}<0.01)$. The comparisons showed significant improvements over the trait-only and the method-only models, therefore we used the traitmethod-error model to test construct validity. Results are detailed in Table 5 and confirm the validity of the measures of CRS.

---Table 5 about here ---

\subsection{Study 4: Assessment of Predictive Validity}

Our fourth study was run to further validate the CRS scale and evaluate in more detail the effect of its dimensions (i.e., demand-base drivers for reshoring) on consumer responses toward reshoring companies. Participants responded to the CRS scale and to measures of specific consumer

consequence of processing of characteristics of reshoring by consumers. Given these differences and premises, the relationship between patriotism and CRS needs to be examined. 
behaviors, that is, attitude toward the reshoring company (Grappi, Romani, \& Bagozzi, 2013a), positive word-of-mouth (Grappi et al., 2013a), and intentions to buy products of the reshoring company (Grappi et al., 2015). We measured both attitudes and behavioral intentions because these types of outcomes capture two critically important ends of consumer response possibilities. Attitudes can be considered a combination of affective and evaluative mental events related to a specific issue and have the capacity to be stored in memory over a long period of time and retrieved under appropriate conditions to orient future judgments. As discussed by psychologists (e.g., Fazio 1995) and marketing scholars (e.g., Bagozzi \& Dholakia 2006), attitudes do not necessarily have a direct connection to action, but they require an additional motivational impetus. Thus, attitudes toward the company signal the impact of company decisions on evaluations by consumers. Word-of-mouth and intention to buy, by contrast, reflect the extent to which consumers are willing to engage in actions toward the company in order to support it by buying its products and/or encouraging others to purchase.

To ascertain possible contamination of consumer responses and potential systematic biases in the CRS scale, we added the social desirability scale (with items selected from Netemeyer, Burton, \& Lichtenstein, 1995) to the questionnaire. To strengthen findings, we decided to collect data for reshoring cases in two different industries. We selected the fashion industry, where the product considered in the reshoring description was a shirt, and the electronics industry, where the product selected was an advanced food processor. These two products differ in the sense that the first belongs to one of the industries associated closely with high quality in Italy, while the second is not recognized particularly as a typical Italian product. Moreover, our choice of these two products aims to cover a wide spectrum of consumer product involvement and general expertise with products. This choice ensures greater generalizability and reliability of results, eliminating the risk of findings biased by a possible product-specificity effect ${ }^{2}$. Details on the research methodology and sampling procedures followed in this study are given in Table 1.

\footnotetext{
${ }^{2}$ A pilot study was run first with 60 undergraduate and graduate students who were asked to evaluate their involvement (Thelen, Yoo, \& Magnini, 2011) and product expertise (Grappi et al., 2015) with the two specific
} 


\subsubsection{Data analysis and results}

A CFA model using LISREL 8.8 (Jöreskog \& Sörbom, 1996) was performed to check the structure of the CRS scale. Results showed a satisfactory level of goodness-of-fit for the sixdimensional 18-item measurement model: $\left(\chi^{2}(120)=481.35 ; \mathrm{p}=0.00 ; \mathrm{CFI}=0.96 ; \mathrm{NNFI}=0.95\right.$; RMSEA $=0.09 ;$ SRMR $=0.06$ ). The composite reliability coefficient of each dimension was also highly satisfactory, ranging from a minimum of 0.89 and a maximum of 0.97 . Correlation levels between the six dimensions of CRS and Social Desirability (Netemeyer et al., 1995) were also checked. To this end, four commonly used items of the Social Desirability scale were used to perform analyses (Grappi, Romani, \& Bagozzi, 2013b; Romani, Grappi, \& Bagozzi, 2013). All correlation values proved to be negligible (all were non-significant and below 0.18 ) highlighting weak and nonconcerning relationships among dimensions. These results confirmed that respondents provided genuine responses uncontaminated by social desirability biases.

Structural equation models (LISREL 8.8; Jöreskog \& Sörbom, 1996) were then run to evaluate the usefulness of the CRS scale in predicting consumer responses in favor of the reshoring company. To evaluate the true impact of each CRS dimension, the two specific types of products used in this study were considered in the analyses including, as a control, a dichotomous variable identifying the specific version of the questionnaire exposed to (reshored shirt or reshored food processor). Table 6 reports the results. Given the fact that these analyses consider many and potentially related variables, multicollinearity was assessed. The variance inflation factor (VIF) was under 5 for each variable, confirming that analyses are not seriously distorted in impact size and direction (Kutner, Nachtsheim, \& Neter, 2004; Rogerson, 2001).

---Table 6 about here ---

\subsubsection{Discussion on the predictive ability of the CRS}

products on 7-point scales from low to high. Respondents showed different levels of involvement $(t(118)=2.45$; $p<0.05)$ and product expertise $(t(118)=6.01 ; p<0.001)$ for the two products. The food processor showed a lower level of product involvement $(M=3.39 ; S D=1.54)$ and product expertise $(M=2.98 ; S D=0.97)$, whereas the shirt, the highest levels of product expertise $(M=4.07 ; S D=1.02)$ and involvement $(M=4.04 ; S D=1.36)$. 
Interesting observations arise from the results, supplementing the findings of Studies 1-3. Taking into consideration the structure of influence for each consumer response, results highlight the important role played by "quality superiority of the reshored products" and "ethical issues in the host countries", which were found to affect all three consumer responses investigated. Focusing on the attitude toward the reshoring company, results showed that the higher the perceived quality of the reshored production and the stronger the consumer connection with the "made-in" elements, the more positive consumer attitudes toward the reshoring company. This mechanism is also enriched by the effect of consumer ethical beliefs connected to reshoring; the more a consumer is inclined to consider reshoring as an ethical company behavior, the more positive his/her attitude toward the reshoring company. Results seem to highlight also that consumers have to rely on the greater ability of the home-country workers (competency availability) and in the commitment of the government in sustaining the reshoring decisions (government support) in order to move from positive evaluations of the reshoring companies to promote positive comments about these companies (i.e., positive word of mouth). The most important dimension affecting intention to buy products of a reshoring company is the one representing consumer beliefs that government and institutions should favor reshoring companies, in order to fight against job losses in the home country. Probably, in this case, the support and help that consumers manifest through buying products of reshoring companies is accompanied by an explicit request to government and institutions to act accordingly, by sustaining the same companies through, for example, laws and policies simplifying reshoring. In this case, it is worth noting the positive influence of the perceived greater ability to fulfil needs of the reshored products in affecting consumer intention to buy, together with the other relevant dimensions.

\subsection{Study 5: Cross-country Validation of the CRS scale and Empirical Segmentation of}

\section{Consumers}

To test the cross-national applicability of the CRS scale, in Study 5 we collected data in the U.S. to compare them with those collected in Italy. The selection of these two countries is based on the following considerations: (a) both Italy and the U.S. are highly developed countries, but exhibit very important differences according to the values framework proposed by Schwartz $(1992 ; 1994)$ (i.e., Italy is reflective of a culture that values high conservatism/low self-enhancement, whereas the 
U.S. is reflective of a culture that values low conservatism/high self-enhancement); and (b) Italy and the U.S. result among the countries most affected by the reshoring phenomenon (Fratocchi et al., 2016). Thus, the U.S. offers an interesting study setting for the purpose at hand by ensuring a meaningful cross-country validation of the CRS scale. Details on the research methodology and sampling procedures followed in this study are presented in Table 1, along with the characteristics of the sample used.

\subsubsection{Cross-country validation of the CRS scale}

Measure Invariance. We first conducted a CFA on the 18-item CRS scale adapted to the U.S. context (e.g., the items of the competency availability and the "made-in" effect dimensions are now referred to the U.S. workers and "Made in U.S." effect). This analysis showed that the 18 -item scale showed excellent fit $(\chi 2(120)=246.80 ; p=0.00 ; \mathrm{CFI}=0.98 ; \mathrm{NNFI}=0.98 ; \mathrm{RMSEA}=0.06$; SRMR=0.05) and all factor loadings were substantial and significant, ranging from 0.87 to 0.94 . Next, we compared the data collected in Italy and U.S. Configural invariance for the 18 -item CRS scale was established, as an acceptable group-model fit was obtained $(\chi 2(240)=730.31 ; p=0.00$; $\mathrm{CFI}=0.97 ; \mathrm{NNFI}=0.96 ; \mathrm{RMSEA}=0.09 ; \mathrm{SRMR}=0.06$ ). To test for metric invariance, we constrained all factor loadings to be equal across countries using covariance matrixes; this constrained model also yielded a satisfactory fit $(\chi 2(252)=746.72 ; p=0.00 ; \mathrm{CFI}=0.97 ; \mathrm{NNFI}=0.96 ; \mathrm{RMSEA}=0.09$; $\mathrm{SRMR}=0.06)$. $\mathrm{A} \chi^{2}$ difference test between the two models was non-significant $(\Delta \chi 2(12)=16.41, \mathrm{p}>$ 0.10), supporting full metric invariance of the CRS scale.

\subsubsection{Segmenting Consumers on CRS.}

To develop an empirically based typology of market segmentation based on the CRS concept, we applied a cluster analysis approach on the U.S. data, grouping respondents depending on their responses on the CRS scale. In order to obtain more complete and interesting information, also the level of ethnocentrism of the respondents was included in this analysis. We selected this variable for segmenting consumers, together with CRS, because (a) ethnocentrism is close to but different from consumer reshoring sentiment (as developed above; § 3.3.2) and (b) its role in explaining consumer responses to reshoring has been demonstrated before (Grappi et al. 2015). Thus, segmenting consumers using both CRS and ethnocentrism provides a demanding test of the CRS scale and can 
give interesting insights on the differential role of the two dimensions in explaining consumer responses to reshoring.

Mean scores for both CRS and ethnocentrism for each respondent provided the basis for a two-step clustering procedure (Punj \& Stewart, 1983; Riefler, Diamantopoulos, \& Siguaw, 2012). In the first step, Ward's hierarchical clustering method with squared Euclidean distances was used to identify clusters within the data. The elbow criterion suggested a four-cluster solution. In the second step, a non-hierarchical, k-means clustering procedure (MacQueen, 1967) was used to develop a fourcluster solution. Internal validity of the cluster solution was tested applying multivariate analysis of variance (Maute \& Dubé, 1999), in which the clusters were compared in terms of all the original items of the CRS and ethnocentrism scales. Significant differences between the clusters were found using Hotelling's trace statistic $(T=6.05, F(66,662)=20.24, p<0.001)$, providing strong evidence for the internal validity of the four-cluster solution. Table 7 summarizes the resulting segments.

--- Table 7 about here ---

Ethnocentric reshoring advocates. This segment is composed of consumers who score high on both CRS and ethnocentrism. These consumers express strong and positive sentiments towards reshoring decisions, supported by strong ethnocentric orientations. This cluster is the largest in the sample.

Reshoring advocates. Consumers in this segment are characterized by low levels of consumer ethnocentrism while showing strong reshoring sentiments. Those belonging to this cluster share positive sentiments towards the reshoring decisions, independently from their (low) ethnocentric orientation. In terms of size, this segment is the second smallest in the sample.

Ethnocentric reshoring neutrals. These consumers are characterized by quite high levels of consumer ethnocentrism and weak reshoring sentiments. Consumers in this segment evaluate the reshoring decisions of a company mainly through ethnocentric lenses. Thus, prejudices against imports or the immorality of buying imported products characterize these respondents in their evaluations of reshored products (more than the specific beliefs that generate reshoring positive sentiments). This segment is the second largest in the sample. 
Reshoring neutrals. Consumers in this cluster express a low level of consumer ethnocentrism and relatively weak reshoring sentiments, scoring moderately low on both CRS and ethnocentrism. This means that the way they look at reshoring does not lead to particularly positive evaluations, and indeed, result in modest strength. In terms of size, this segment is the smallest one.

Profile and consumption tendencies of the segments. The clusters were then profiled. First, $\chi^{2}$ tests were used to compare clusters on relevant demographic variables; then one-way ANOVAs were run to compare segments on relevant consumer responses to reshoring. The clusters did not differ in age $\left(\chi^{2}(9)=14.61, p=0.10\right)$, level of education $\left(\chi^{2}(6)=4.31, p=0.64\right)$, or gender $\left(\chi^{2}(3)=0.27, p=\right.$ 0.97), showing that a description using only demographic variables is not effective in differentiating segments. The four clusters were then analyzed profiling the consumers in terms of attitude toward the reshoring company, word of mouth in favor of the company, and willingness to buy its products. Following the literature (Grappi et al., 2015), ethnocentric consumers were expected to show more favorable evaluations and responses to reshoring. In addition, consumers with strong reshoring sentiments were expected to show similar more positive responses compared to consumers with lower sentiments toward reshoring, as detailed above. Consequently, we expected to find more positive responses to reshoring companies (i.e., more positive attitudes, stronger intentions to spread positive word of mouth, and higher intentions to buy the reshoring company products) among "ethnocentric reshoring advocates" compared with the other segments.

Using one-way ANOVAs, we found significant differences across the clusters in terms of attitude toward the company $(F(3,243)=14.64, \mathrm{p}<0.01)$, word of mouth $(F(3,243)=31.76, \mathrm{p}<0.01)$, and intention to buy $(F(3,243)=55.82, \mathrm{p}<0.01)$. In detail, pairwise comparisons (Table 8$)$ showed that the cluster scoring high on both reshoring sentiments and ethnocentrism (i.e., "ethnocentric reshoring advocates") showed significantly higher positive consumer responses than the cluster scoring lower for both reshoring sentiment and ethnocentrism (i.e., "reshoring neutrals") and the cluster scoring lower for reshoring sentiments (i.e., "ethnocentric reshoring neutrals"). More interesting, the cluster "reshoring advocates" reached the same positive score of the "ethnocentric reshoring advocates" cluster for attitude toward the company, intention to buy the company products, and word of mouth. This means that consumer reshoring sentiments favored consumer positive responses regardless of the 
level of ethnocentrism of respondents, thus confirming the importance of reshoring sentiments and the potential that they offer on company consumer targets. The role of consumer reshoring sentiments is further highlighted in that, for consumers with low scores, responses to reshoring companies are significantly low independent of the level of ethnocentrism of respondents. Thus, regardless of the level of ethnocentrism, CRS proves to enhance consumer responses toward reshoring: the higher consumer reshoring sentiments, the stronger the positive responses to the reshoring company in terms of making supportive choices.

These results confirm that reshoring can be an effective way to increase value created within the company's value system, given the higher and stronger positive responses of segments characterized by high CRS. Thus, the approach aimed at increasing value-creation for consumers through reshoring turns out to be a valuable strategic tool for the company.

---Table 8 about here ---

\section{GENERAL DISCUSSION}

Our study is one of the first to adopt the demand-side perspective in examining the company reshoring decision process, thus adding a new element-namely, Consumer Reshoring Sentiment (CRS)-to the existing knowledge base about reshoring drivers. We define CRS as an appraisal structure formed by six relevant, generalized, long-term positive dimensions related to, respectively, "superior quality of the reshored production", "made-in effect", “competency availability”, "government support", "greater ability to fulfill needs", and "ethical issues in host countries". We also conceptually and empirically demonstrated the sentiment's distinctiveness from two theoretical related constructs, that is, consumer ethnocentrism and patriotism. Given the specificities of the relocation decisions, we demonstrated the opportunity to carefully distinguish the consumer reshoring sentiment from the general, positive orientations towards domestic products of the two related constructs (e.g., Han, 1988; Herche, 1992). To this end, we advanced a specific measurement instrument to assess properly the CRS construct. The 18-item, six-dimension CRS scale achieved satisfactory psychometric properties across countries, samples, and studies. The convergent and discriminant validity of the measures were also demonstrated by use of an MTMM matrix design. 
Therefore, the CRS scale is a valid and useful tool for measuring important beliefs of consumers concerning reshoring.

The CRS dimensions identified are also related to criteria that are of interest to strategic management decisions. In line with previous research that found that reshoring is a way to better satisfy new demand characteristics (Ancarani et al., 2015; Martinez-Mora \& Merino, 2014) and that consumers show a greater willingness to buy/pay for reshored products (Grappi et al., 2015), our study, while using new ideas and new, validated measures underpinning consumer sentiments, not only confirms such outcomes but adds new insights, as discussed below. Specifically, our findings show that (a) consumers are inclined to develop positive associations with reshoring (i.e., reshoring increases consumer perceived value of the company's offers), and (b) the stronger the CRS, the stronger consumer willingness to reward the reshoring company by buying its products and spreading approval by word-of-mouth (i.e., reshoring increases the value created within the company's value system).

Finally, the effectiveness of the CRS construct was also shown in segmenting and targeting the home-country market. Cluster analysis results showed the presence of different segments on the basis of reshoring sentiment and the level of ethnocentrism of consumers (i.e., the categories were "ethnocentric reshoring advocates", "reshoring advocates", "ethnocentric reshoring neutrals", and "reshoring neutrals"). The identified clusters are characterized by different responses to company reshoring, confirming the opportunities offered by the CRS construct to effectively profile and target the home-country market when a company implements a reshoring decision. In fact, the numerous possibilities that companies now have to get in touch with the market (e.g., contacting actual customers and prospects through social media) allow firms to obtain more detailed information, compared to only collecting consumer demographics data. By asking consumers to answer the items of the CRS scale through pools posted on social media, a company evaluating reshoring can a) identify the reshoring sentiment of the contacted consumers, thereby helping to better segment them; b) foresee their responses based on the general level of this sentiment; and c) prioritize the different dimensions underlying CRS (i.e., the six demand-side drivers) by identifying the prominent ones. All this opens promising opportunities for companies. The identification of the most prominent demand- 
side drivers for reshoring can tell the company what elements are primarily associated with reshoring by home-country consumers in the specific context of interest and, consequently, which of them could be leveraged to achieve the most favorable reactions. For example, if "superior quality of the reshored production" emerges among the first demand-side drivers for reshoring to be acknowledged by the target, the company receives accurate indications as to which elements it should stress to optimize market responses (e.g., the company can clearly state that the main reason for bringing back activities to the home country is to better control the production process and, thus, ensure higher quality standards). If "competency availability" emerges as the most prominent demand-side driver, different elements can be used by the company (e.g., the company can publicly acknowledge as its main reasons for reshoring the superior capabilities and skills of the home-country workers, thus favoring the most positive responses of the target). Ultimately, the analysis of the consumer reshoring sentiment, and of the underlying components, allows the company to a) establish if and to what extent the home-country market is willing to reward the major strategic move of reshoring and b) detect which elements leverage on to maximize returns.

\subsection{Theoretical contribution}

Company reshoring decisions require the consideration of multiple elements, internal and external, quantitative and qualitative. Considering and integrating these elements, which are very different in nature, can be very useful but extremely difficult for companies (Gray at al., 2013). Our research helps by adding to the existing firm-side arguments for reshoring decisions a new perspective that looks outside the company towards the market. In so doing, this work makes new theoretical contributions. First, it offers a richer perspective on the drivers affecting the company reshoring decision, by suggesting a role for home-country consumers' input, which should be considered together with other elements identified by current literature. We develop a demand-side argument on the motivations for reshoring to complement the well-established firm-side research (e.g., Canham \& Hamilton; Casson, 2013; Dachs \& Kinkel, 2013; Dachs \& Zanker, 2015; Ellram et al. 2013;Fratocchi et al. , 2016; Gray et al. 2013; Kinkel \& Maloca, 2009; Kinkel \& Zanker, 2013; Kinkel, 2012; 2014; Kinkel \& Maloca, 2009; Martínez-Mora \& Merino, 2014; Nujen et al., 2015; Wu \& Zhang, 2014). Demand-side perspectives recognize reshoring as a way to increase value created within the 
company's value system by emphasizing value-creation for consumers, thus clearly differing from the current firm-side point of view on reshoring drivers and motivations. Until now, scholars have investigated the reshoring decision as mainly oriented by evaluations focused on cost- and resourcebased drivers, whereas little is known about the characteristics and reactions of the home-country market and the role that these play in the company decision process. This is a point of emphasis within this study: that introducing demand-side perspectives to an IB context helps us to better understand reshoring beyond the firm-side motivations that have provided the primary explanation in previous research. The main contribution of this paper is to bring an important, but largely ignored, group of subjects (home-country consumers) into the discussion about the company reshoring decision process.

Second, our research accurately conceptualizes the consumer reshoring sentiment construct and identifies the underlying consumers' beliefs about reshoring (i.e., superior quality of the reshored production, "made-in" effect, competency availability, government support, greater ability to fulfill needs, and ethical issues in host countries). These beliefs can be seen as the set of positive, affective and cognitive evaluations of reshoring shared by home-country consumers, informing their behavioral responses in the home-country market. In this research we provide a valid, reliable, and manageable measuring instrument of the CRS, also showing empirically that this sentiment can predict which types of response consumers will have towards reshoring companies. The effectiveness of the CRS in analyzing the home-country market has been demonstrated, giving new insights to companies on how to deal with the home-country consumers.

Finally, by expanding existing IB research on reshoring through the inclusion of demandbased drivers for reshoring, we explicitly answer the call to examine the role of the demand characteristics in explaining the company decision-making process (Priem et al., 2012; Siqueira et al., 2015). We identify consumer beliefs about reshoring and suggest that companies take them into consideration in their reshoring decisions, together with the cost- and resource-based considerations identified in previous IB research. In this way consumer issues are raised from the tactical to the strategic level, enriching IB research through the development of an additional, measurable pillar, 
useful to take into consideration in the company's reshoring decision, namely: Consumer Reshoring Sentiment.

\subsection{Managerial Implications}

Our research has practical relevance for managers and practitioners dealing with company relocation decisions. Specifically, our work may assist in several domains. First, our scale provides companies with a useful tool to understand consumer sentiment toward reshoring in general. By using a composite analysis of the entire scale, companies can gain initial insight into the overall effects of reshoring decisions on their own customers and, more generally, on the public at large, checking to see whether these effects are in line with those expected by the reshoring company. Then, by examining the differential roles of the specific dimensions of CRS, and tracking analyses of their evolution and effects over time, companies should be able to identify market responses to reshoring in advance, gaining a better understanding of the general consumer evaluation of reshoring and obtaining useful suggestions on how to maximize value created for the company. Considering, for example, the CRS dimension "ethical issues in host countries", the major strategic move of reshoring can provide a consumer-based competitive advantage strongly centered on ethical issues. A recent example of a company that leveraged on this dimension is Apple. In 2012 Apple reshored the assembly of a line of Mac computers from China to the U.S.. Apple accompanied this move with explanations about the ethical need to stop the exploitation of Asian labor and to cease taking advantage of lax labor standards abroad (Smith, 2014). Another interesting example is that of Burberry, a high-end apparel UK firm that leveraged on the "made-in effect" and "competency availability" CRS dimensions to explain reshoring and strengthen its competitive advantage. From the mid-2000s, Burberry began to reshore activities to the UK, acknowledging the high value of the "made in Britain" marker in capitalizing on the brand's heritage. In 2015, the CEO of Burberry stated that they strongly believed in British manufacturing and in the hardly replaceable skills of the UK workforce, publicly declaring the decision of Burberry to continue to build on these elements (Robinson \& Hsieh, 2016).

Additional benefits can be identified with respect to the usefulness of the CRS scale in homecountry market segmentation and profiling. Our findings suggest that the identification and 
subsequent targeting of consumers with strong reshoring sentiments (i.e., "ethnocentric reshoring advocates" and "reshoring advocates" segments) can be effective strategies for reshoring companies. Communication targeting these consumer groups should emphasize "(re)made in the home country" messages with the purpose of capitalizing primarily on the reshoring sentiments of these consumers, and also on their ethnocentric tendencies, when present. These messages may be extremely effective for those consumers who, as previously noted, (1) show strong reshoring sentiments, (2) display an increased willingness to support reshoring companies (through, for example, their willingness to buy and pay for their products), and (3) in one case (i.e., "ethnocentric reshoring advocates" cluster), are ethnocentric. To the extent that these segments are large and substantial, "(re)made in the home country" communication campaigns may be very successful and achieve favorable effects. Our results suggest to reshoring companies that they target differently (and specifically) these consumers, as they are likely to be more responsive to company efforts emphasizing aspects of (re)localization of productions to the home country, and developing consistent positioning strategies.

\subsection{Limitations and Future Research}

Our study provides interesting insights addressing the demand-side perspective in examining reshoring, which deserves increasing attention by researchers and managers responsible for corporate location decisions. But a number of limitations, and hence opportunities for future research, should be mentioned. First, our study relied on qualitative evidence and quantitative self-reported measures, which may restrict the conclusions that can be drawn from the findings. Although evidence for actions was found in Studies 4 and 5, it is important that different consumer responses to reshoring (e.g., consumer willingness to pay for reshored products) be considered in the future in order to broaden and deepen our understanding of how this decision is able to increase the value created for companies. At the same time, different types of reshoring (e.g., full reshoring or partial reshoring of the company activities) can be considered in future research to highlight possible specificities. In addition, the CRS scale developed herein is primarily focused on product reshoring decisions; future studies may broaden their range of action by applying the CRS scale in different contexts, such as that of services reshoring. In fact, recent research has shown that reshoring decisions of business services previously offshored (Albertoni et al., 2017) deserve specific attention. At the same time, future studies can test 
the CRS scale in different industries. We selected the fashion and the electronics industries for the assessment of the predictive validity of our scale (see Study 4), but testing the CRS scale in additional industries can be an important research opportunity. At the same time, future research could apply a longitudinal analysis in order to discover how the consumer sentiment toward reshoring evolves and forms, thereby gaining new and useful insights.

It is worth noting that, although our findings imply that CRS affects important consumer responses, our results do not imply that this element is the only demand-based driver of such reactions. Consumer individual characteristics (e.g., cosmopolitanism, materialism) could also play roles in influencing such outcomes by either bolstering or suppressing CRS effects. Further research should examine these possibilities to complement findings. Indeed, it is possible that consumers may differ systematically in their support for or against reshoring, reflecting perhaps value differences in consumer vs business interests, and this seems a promising area for future research. Furthermore, although our study focused on (and identified) the positive beliefs consumers associate with reshoring, an area of interest for future research would be to systematically analyze possible negative associations that consumers may develop towards reshoring, and which did not emerge in our research (e.g., higher prices of reshored products compared to offshored products), in order to supplement our findings.

Moreover, our work is clearly consumer-oriented and shows interesting, and sound, findings for companies operating in the business-to-consumer (B2C) context, but it does not address the business-to-business (B2B) area. While on the one hand our results are especially useful for B2C businesses, on the other hand they suggest interesting opportunities for future insights into the B2B area, which is currently not adequately addressed and deserves to be specifically considered in further research.

In addition, our research took place in the years characterized by the first positive signs of economic upturn after a period of deep economic crisis, starting in about 2007. The test of the CRS scale under more stable and favorable economic conditions, to understand whether and in what terms it is affected by economic conditions and trends, could be interesting and useful research opportunities. At the same time, future research can test the CRS construct and its effects in different 
countries. In fact, our work focused on Italian and American markets which represent CRS construct characteristics in developed countries. Italy is experiencing severe social pressures due to strong immigration flows, whereas the U.S. is undergoing a deep political change from Democratic party to Republican party orientations. Although the CRS scale, to ensure greater reliability, has thus been tested on two countries characterized by very different political and social pressures, these issues might have affected the results and are worth investigating. Future studies should be conducted in different countries, less affected by these types of political and social issues, to further validate the CRS scale. Moreover, future research should also apply the CRS scale in countries less affected by the reshoring phenomenon so as to reveal possible differences in CRS and its structure and effects and thereby discover its boundary conditions. 


\section{ACKNOWLEDGMENT}

Sincere thanks are due to Richard L. Priem for his insightful advice and support. 


\section{REFERENCES}

Albertoni, F., Elia, S., Massini, S. \& Piscitello, L. (2017). The reshoring of business services: Reaction to failure or persistent strategy? Journal of World Business, 52 (3), 417-430.

Ancarani, A., Di Mauro, C., Fratocchi, L., Orzes, G., \& Sartor, M. (2015). Prior to reshoring: A duration analysis of foreign manufacturing ventures. International Journal of Production Economics, 169, 141-155.

Arnold, M. B. (1969). Emotion and Personality, Vol. 1 Psychological Aspects. New York: Columbia University Press.

Bagozzi, R.P. (2011). Measurement and Meaning in Information Systems and Organizational Research: Methodological and Philosophical Foundations. MIS Quarterly, 35 (2), 261-292.

Bagozzi, R. P. \& Dholakia, U. M. (2006). Antecedents and purchase consequences of customer participation in small group brand communities. International Journal of Research in Marketing, 23, 45-61.

Bagozzi, R.P. \& Edwards, J.R. (1998). A General Approach for Representing Constructs in Organizational Research. Organizational Research Methods, 1, 45-87.

Bagozzi, R.P., Yi, Y., \& Phillips, L.W. (1991). Assessing Construct Validity in Organizational Research. Administrative Science Quarterly, 36, 421-458.

Bailey, N. \& Li, S. (2015). Cross-national Distance and FDI: The Moderating Role of Host Country Local Demand. Journal of International Management, 21 (4): 267-276.

Balabanis, G., Diamantopoulos, A., Mueller, R.D., \& Melewar, T.C. (2001). The Impact of Nationalism, Patriotism and Internationalism on Consumer Ethnocentric Tendencies. Journal of International Business Studies, 32 (1), 157-175.

Barney, J. (1991), "Firm resources and sustained competitive advantage", Journal of Management, 17 (1), 99-120.

Bharadwaj, N. \& Roggeveen, A.L. (2008). The impact of offshored and outsourced call service centers on customer appraisals. Marketing Letters, 19, 13-23. 
Blinder, A. S. (2007). How Many U.S. Jobs Might Be Offshorable? CEPS working paper no. 142.

Retrieved November 11, 2008 from http://www.princeton.edu/\%7Eblinder/articles.htm\#2007.

Buckley, P.J. \& Casson, M. (1976). The Future of the Multinational Enterprise. London: The Macmillan Press.

Buckley, P. \& Casson, M. (2011). Marketing and the multinational: extending internalization theory. Journal of the Academy of Marketing Science, 39 (4), 492-508.

Canham, S. \& Hamilton, R. T. (2013). SME internationalisation: Offshoring, "backshoring”, or staying at home in New Zealand. Strategic Outsourcing: An International Journal, 6 (3), 277291.

Casson, M. (2013). Economic analysis of international supply chains: an internalization perspective. Journal of Supply Chain Management, 49 (2), 8-13.

Churchill, G. A., Jr. \& Iacobucci, D. (2002). Marketing research methodological foundations (8th ed.). Fort Worth: Harcourt College Publishers.

Dachs, B. \& Kinkel, S. (2013). Backshoring of production activities in European manufacturing: evidence from a large scale survey. In: B. Fynes \& P. Coughlan (Eds), Operations Management at the Hearth of the Recovery, Proceedings of the 20th EurOMA Conference.

Dachs, B. and Zanker, C. (2015), "Backshoring of production activities in European manufacturing", MPRA Paper No. 63868, available at: http://mpra.ub.uni-muenchen.de/63868/ (accessed June 14, 2017).

Dennis, J. M., Chatt, C., Li, R., Motta-Stanko, A., \& Pulliam, P. (2005). Data Collection Mode Effects Controlling for Sample Origins in a Panel Survey: Telephone versus Internet. (Draft Copy), Retrieved February 08, 2016 from http://www.websm.org/uploadi/editor/1130673305research0105.pdf.

DeVellis, R. (2003). Scale development: Theory and applications. Thousand Oaks, CA: Sage.

Duffy, B., Smith, K., Terhanian, G., \& Bremer, J. (2005). Comparing data from online and face-toface surveys. International Journal of Market Research, 47, 615-639.

Dunning, J.H. (1980). Toward an eclectic theory of international production: some empirical tests. Journal of International Business Studies, 11 (1), 9-31. 
Dunning, J.H. (1998). Location and the multinational enterprise: a neglected factor? Journal of International Business Studies, 29 (1), 45-66.

Ellram, L.M. (2013). Offshoring, reshoring and the manufacturing location decision. Journal of Supply Chain Management, 49 (2), 3-5.

Ellram, L. M., Tate, W. L., \& Petersen, K. J. (2013). Offshoring and reshoring: An update on the manufacturing location decision. Journal of Supply Chain Management, 49 (2), 14-22.

Fazio, R. H. (1995). Attitudes as object-evaluation associations: Determinants, consequences, and correlates of attitude accessibility. In R. E. Petty \& J. A. Krosnik (Eds.), Attitude strength: Antecedents and consequences (pp. 247-282). Mahwah: Erlbaum.

Feshbach, S. (1990). Psychology, Human Violence, and the Search for Peace: Issues in Science and Social Values. Journal of Social Issues, 46, 183-198.

Fornell, C. \& Larcker, D. F. (1981). Evaluating structural equation models with unobservable variables and measurement error. Journal of Marketing Research, 18 (1), 39-50.

Fratocchi, L., Ancarani, A., Barbieri, P., Di Mauro, C., Nassimbeni, G., Sartor, M., Vignoli, M., \& Zanoni, A. (2016). Motivations of manufacturing reshoring: an interpretative framework. International Journal of Physical Distribution \& Logistics Management, 46 (2), 98-127.

Fratocchi, L., Barbieri P., DiMauro C., Nassimbeni G., \& Vignoli M. (2013). Manufacturing backreshoring - an exploratory approach for hypotheses development. Paper Presented at the XXIV Riunione Scientifica Annuale AiIG. Milan, Italy, 17-18 October. http://papers.ssrn.com/sol3/papers.cfm?abstract_id=2333106

Fratocchi, L., Di Mauro, C., Barbieri, P., Nassimbeni, G., \& Zanoni, A. (2014). When manufacturing moves back: Concepts and questions. Journal of Purchasing and Supply Management, 20 (1), $54-59$.

Fratocchi, L., Nassimbeni G., Zanoni A., Ancarani A., Valente M. E., Sartor M., Barbieri P., DiMauro C,. \& Vignoli, M. (2011). Manufacturing back-shoring: a research agenda for an emerging issue in international business. Paper Presented at the $37^{\text {th }}$ European International Business Academy Annual Conference 2011. Bucharest, Romania, 8-10 December. 
Frijda, N.H., \& Mesquita, B., (2000). Beliefs through emotions. In N. H. Frijda, A. S. R. Manstead, \& S. Bem (Eds), Emotions and Beliefs-How feelings influence thoughts. Cambridge: Cambridge University Press.

Gerbing, D. W. \& Anderson, J. C. (1988). An updated paradigm for scale development incorporating unidimensionality and its assessment. Journal of Marketing Research, 25 (2), 186-192.

Grappi, S., Romani, S., \& Bagozzi, R.P. (2013a). The effects of company offshoring strategies on consumer responses. Journal of the Academy of Marketing Science, 41 (6), 683-704.

Grappi, S., Romani, S., \& Bagozzi, R.P. (2013b). Consumer response to corporate irresponsible behavior: Moral emotions and virtues. Journal of Business Research, 66 (10), 1814-1821.

Grappi, S., Romani, S., \& Bagozzi, R.P. (2015). Consumer stakeholder responses to reshoring strategies. Journal of the Academy of Marketing Science, 43 (4), 453-471.

Gray, J.V., Skowronski, K., Esenduran, G., \& Rungtusanatham, J. M. (2013). The Reshoring Phenomenon: What Supply Chain Academics Ought to know and Should Do. Journal of Supply Chain Management, 49 (2), 27-33.

Hair, J. F., Jr., Black, W. C., Babin, B., Anderson, R. E., \& Tatham, R. L. (2005). Multivariate data analysis with reading (6th ed.). Upper Saddle River: Prentice Hall/Pearson Education.

Han, C. M. (1988). The role of consumer patriotism in the choice of domestic versus foreign products, Journal of Advertising Research, 28 (June/July), 25-32.

Herche, J. (1992). A note on the predictive validity of the CETSCALE. Journal of the Academy of Marketing Science, 20 (3), 261-264.

Houseman, S. (2007). Outsourcing, offshoring and productivity measurement in United States manufacturing. International Labour Review, 146, 61-80.

Hu, L. \& Bentler, P.M. (1999). Cutoff criteria for fit indexes in covariance structure analysis:

Conventional criteria versus new alternatives. Structural Equation Modeling: A Multidisciplinary Journal, 6, 1-55.

Javalgi, R.G., Cutler, B.D., \& Winans, W.A. (2001). At your service! Does country of origin research apply to services? Journal of Services Marketing, 15, 565-582. 
Jöreskog, K. G. \& Sörbom, D. (1996). LISREL 8, user's reference guide. Lincolnwood, IL: Scientific Software International.

Kedia, B. L. \& Mukherjee, D. (2009). Understanding offshoring: A research framework based on disintegration, location and externalization advantages. Journal of World Business, 44 (3): 250261.

Kinkel, S. (2014). Future and impact of backshoring-Some conclusions from 15 years of research on German practices. Journal of Purchasing and Supply Management, 20 (1), 63-65.

Kinkel, S. (2012). Trends in production relocation and backshoring activities: Changing patterns in the course of the global economic crisis. International Journal of Operations \& Production Management, 32 (6), 696-720.

Kinkel, S. \& Maloca, S. (2009). Drivers and antecedents of manufacturing offshoring and backshoring-A German perspective. Journal of Purchasing and Supply Management, 15, $154-165$.

Kinkel, S. \& Zanker, C. (2013). New patterns of German production relocation and back shoring activities after the global economic crisis. In: B. Fynes \& P. Coughlan (Eds), Operations Management at the Hearth of the Recovery, Proceedings of the 20th EurOMA Conference.

Knudsen, M.P. \& Servais, P. (2007). Analyzing internationalization configurations of SME's: The purchaser's perspective. Journal of Purchasing and Supply Management, 13 (2), 137-151.

Kosterman, R. \& Feshbach, S. (1989). Toward a measure of patriotic and nationalistic attitudes. Political Psychology, 10(2), 257-274.

Krause, R., Filatotchev, I., \& Bruton, G. D. (2016). When in Rome, look like Caesar? Investigating the link between demand-side cultural power distance and CEO power. Academy of Management Journal, 59 (4), 1361-1384.

Kutner, M. H., Nachtsheim, C. J., \& Neter, J. (2004). Applied Linear Regression Models (4th ed.). McGraw-Hill Irwin

MacQueen, J. (1967). Some methods for classification and analysis of multivariate observations. In L.A. Le Cam \& J. Newman (Eds), Proceedings of the 5th Berkeley Symposium on Mathematical Statistics and Probability. 281-297. Berkeley, CA: University of California Press. 
Marsh, H.W. \& Hocevar, D. (1985). Application of confirmatory factor analysis to the study of selfconcept: First-and higher order factor models and their invariance across groups. Psychological Bulletin, 97 (3), 562-582.

Martínez-Mora, C. \& Merino, F. (2014). Offshoring in the Spanish footwear industry: A return journey? Journal of Purchasing and Supply Management, 20, 225-237.

Maute, M. F. \& Dube, L. (1999). Patterns of emotional responses and behavioural consequences of dissatisfaction. Applied Psychology: An International Review, 48 (3), 349-366.

Netemeyer, R.G., Bearden, W.O., \& Sharma, S. (2003). Scaling procedures: Issues and applications. London: Sage Publications.

Netemeyer, R.G., Burton, S., \& Lichtenstein, D.R. (1995). Trait aspects of vanity: Measurement and relevance to consumer behavior. Journal of Consumer Research, 21(4), 612-626.

Nujen B.B., Halse L.L., Solli-Sæther H. (2015). Backsourcing and Knowledge Re-integration: A Case Study. In: Umeda S., Nakano M., Mizuyama H., Hibino H., Kiritsis D., von Cieminski G. (eds) Advances in Production Management Systems: Innovative Production Management Towards Sustainable Growth. APMS 2015. IFIP Advances in Information and Communication Technology, vol 460. Springer, Cham.

Nunnally, J.C. \& Bernstein, I.H. (1994). The assessment of reliability. Psychometric Theory, 3, 248292.

Priem, R. L., Li, S., \& Carr, J. C. (2012). Insights and new directions from demand-side approaches to technology innovation, entrepreneurship, and strategic management research. Journal of Management, 38 (1), 346-374.

Punj, G. \& Stewart, D. W. (1983). Cluster analysis in marketing research: Review and suggestions for application. Journal of Marketing Research, 20 (2), 134-148.

Riefler, P., Diamantopoulos, A., \& Siguaw, J. A. (2012). Cosmopolitan consumers as target group for segmentation, Journal of International Business Studies, 43 (3), 285-305.

Robinson, P. K., \& Hsieh, L. (2016). Reshoring: a strategic renewal of luxury clothing supply chains, Operations Management Research, 9 (3/4), 89-101.

Rogerson, P. (2001). Statistical methods for geography. London: Sage Publications. 
Romani, S., Grappi, S., \& Bagozzi, R.P. (2013). Explaining Consumer Reactions to Corporate Social Responsibility: The Role of Gratitude and Altruistic Values. Journal of Business Ethics, 114 (2), 193-206.

Schwartz, S. H. (1992). Universals in the content and structure of values: Theoretical advances and empirical tests in 20 countries. In M. P. Zanna (Ed.), Advances in experimental social psychology, Vol. 25. Orlando, FL: Academic Press.

Schwartz, S. H. (1994). Beyond individualism/collectivism: New cultural dimensions of values. In U. Kim, H. C. Triandis, C. Kagitcibasi, S.-C. Choi, \& G. Yoon (Eds), Individualism and collectivism: Theory, method, and applications, Cross-cultural research and methodology series, Vol. 18: 85-119. Thousand Oaks, CA: Sage.

Shand, A. F. (1922). The relations of complex and sentiments. The Journal of Psychology, 13, $123-$ 129.

Sharma, S., Shimp, T.A., \& Shin, J. (1995). Consumer ethnocentrism: a test of antecedents and moderators. Journal of the Academy of Marketing Science, 23 (1), 26-37.

Shimp, T.A. \& Sharma, S. (1987). Consumer ethnocentrism: construction and validation of the CETSCALE. Journal of Marketing Research, 24, 280-289.

Siqueira, A. C. O., Priem, R. L., \& Parente, R. C. (2015). Demand-side Perspectives in International Business: Themes and Future Directions. Journal of International Management, 21 (4), 261266.

Sirkin, H. L., Zinser, M., Hohner, D., \& Rose, J. (2012). US manufacturing nears the tipping point: which industries? Why, and how much?, BCG Perspectives, Retrieved June 2, 2016 from : www.bcgperspectives.com/content/articles/manufacturing_supply_chain_management_us_man ufacturing_nears_the_tipping_point/

Spiggle, S. (1994). Analysis and Interpretation of Qualitative Data in Consumer Research. Journal of Consumer Research, 21 (December), 491-503.

Smith, P. (2014). Flowback or the end of globalization. IIM Kozhikode Society and Management Review, 3(1), 1-9. 
Tafti, M. H. (2005). Risks factors associated with offshore IT outsourcing. Industrial Management \& Data Systems, 105, 549-560.

Tate, W.L., Ellram, L.M., Bals, L., \& Hartmann, E. (2009). Offshore outsourcing of services: An evolutionary perspective. International Journal of Production Economics, 120 (2), 512-524.

Tate, W. L., Ellram, L., Petersen, K. J., \& Schoenherr, T. (2014a). Current practices in offshoring and reshoring. Council Supply Chain Management Professionals.

Tate, W.L., Ellram, L.M., Schoenherr, T., \& Petersen, K.J. (2014b). Global competitive conditions driving the manufacturing location decision. Business Horizons, 57 (3), 381-390.

Teece, D.J., Pisano, G., \& Shuen, A. (1997). Dynamic capabilities and strategic management. Strategic Management Journal, 18 (7), 509-533.

Thelen, S.T., Yoo, B., \& Magnini, V.P. (2011). An examination of consumer sentiment toward offshored services. Journal of the Academy of Marketing Science, 39 (2), 270-289.

Williamson, O. E. (2008). Outsourcing: transaction cost economics and supply chain management. Journal of Supply Chain Management, 44 (2), 5-16.

Wu X., \& Zhang F. (2014) Home or overseas? An analysis of sourcing strategies under competition. Management Science. 60 (5): 1223-1240.

Zeugner-Roth, K. P., Zabkar, V., \& Diamantopoulos, A. (2015). Consumer Ethnocentrism, National Identity, and Consumer Cosmopolitanism as Drivers of Consumer Behavior: A Social Identity Theory Perspective, Journal of International Marketing, 23 (2), 25-54. 
Table 1. CRS scale development process: Overview of the studies conducted

\begin{tabular}{|c|c|c|c|}
\hline & Aim & Research methodology & Sampling procedures and sample characteristics \\
\hline \multicolumn{4}{|c|}{ Construct definition and item development process } \\
\hline 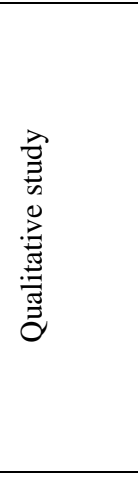 & $\begin{array}{l}\text { Reveal consumers' } \\
\text { multiple beliefs about } \\
\text { reshoring }\end{array}$ & $\begin{array}{l}\text { In-depth interviews were conducted with Italian adult consumers. Each } \\
\text { interview lasted approximately one hour, starting by asking participants to } \\
\text { think of the reshoring phenomenon in general and to relate cases of reshoring } \\
\text { they had heard about or experienced. They were asked to take a few moments } \\
\text { to recall as many ideas as they could, and then to recount as many details as } \\
\text { possible about their thoughts, beliefs, and behaviors related to reshoring. } \\
\text { Participants were asked to be honest, frank, and forthcoming in their } \\
\text { responses, and they were encouraged to express their opinions freely, as well } \\
\text { as to report any specific experiences they considered relevant. Follow-up and } \\
\text { probing questions were asked where necessary to elicit relevant information. } \\
\text { All respondents were able to provide their opinions and experiences, } \\
\text { demonstrating the relevance of the phenomenon for them and, in general, their } \\
\text { positive orientation. }\end{array}$ & $\begin{array}{l}24 \text { subjects of both genders, of different ages, with different levels of } \\
\text { education, and employed both in the private and public sectors, were included. } \\
\text { In detail, the participants had the following characteristics: they ranged in age } \\
\text { from } 20 \text { to } 61,16 \text { were females and } 8 \text { males, } 7 \text { were undergraduate or higher } \\
\text { educated respondents, while the remaining } 17 \text { were less formally educated. } \\
\text { Compensation was not provided for participation. } \\
\text { This preliminary study helped us in (a) revealing the consumer beliefs about } \\
\text { reshoring and (b) developing the measurement scale for constructs, suggesting } \\
\text { items consistent with the specific words and idioms actually used by } \\
\text { consumers. }\end{array}$ \\
\hline 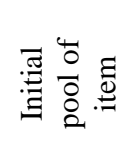 & $\begin{array}{l}\text { Development and } \\
\text { review of the initial } \\
\text { pool of items }\end{array}$ & $\begin{array}{l}\text { Following the qualitative study, a pool of } 41 \text { candidate items, covering the } \\
\text { meaning of CRS dimensions, was created. This set of items was then tested for } \\
\text { clarity, comprehensiveness, and content-validity, using both independent } \\
\text { judges and consumers. }\end{array}$ & $\begin{array}{l}\text { Three independent judges reviewed the first list of items, reducing the pool of } \\
\text { items to } 34 \text {. Then, } 5 \text { adult consumers were asked to pre-test this set of items } \\
\text { for clarity and comprehensiveness. The resulting pool consisted of } 27 \text { items. }\end{array}$ \\
\hline \multicolumn{4}{|c|}{ Quantitative scale purification process } \\
\hline$\underset{\overbrace{}}{\stackrel{Z}{E}}$ & Item refinement & $\begin{array}{l}\text { Data were collected using a self-administered method. A brief initial } \\
\text { description introduced respondents to the questionnaire, asking them to refer } \\
\text { to the reshoring decision considered as the general practice to relocate } \\
\text { activities back to the home country by firms (and not as a reshoring decision } \\
\text { of a specific company). The questionnaire used contained the initial set of } 27 \\
\text { items. Responses ranged between } 1=\text { "strongly disagree" and } 7 \text { = "strongly } \\
\text { agree", with intermediate points labeled. }\end{array}$ & $\begin{array}{l}\text { Qualified respondents (non-student adults) were used. Italian consumers, } \\
\text { randomly contacted to enhance sample validity, were asked to complete the } \\
\text { survey. In total, } 266 \text { surveys were collected, resulting in a } 92.9 \% \text { usability } \\
\text { ratio. Thus, Study } 1 \text { included } 247 \text { responses ( } 53 \% \text { males; average age of } 44 \\
\text { years). }\end{array}$ \\
\hline 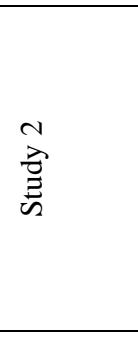 & $\begin{array}{l}\text { Assessment of scale } \\
\text { validity }\end{array}$ & $\begin{array}{l}\text { Data were collected through an online survey to minimize participant social } \\
\text { desirability bias (Dennis, Chatt, Li, Motta-Stanko, \& Pulliam, 2005; Duffy, } \\
\text { Smith, Terhanian, \& Bremer, 2005). In the brief opening description of the } \\
\text { study, respondents were directed to answer questions referring to general } \\
\text { reshoring practices by companies in the home country. The survey included } 19 \\
\text { items derived from Study } 1 \text {, demographic items, and items for assessing } \\
\text { discriminant validity resulting in } 52 \text { items in total. Reshoring sentiment items } \\
\text { were randomly mixed throughout the survey to enhance validity. }\end{array}$ & $\begin{array}{l}\text { A convenience quota sample, composed of qualified respondents (non-student } \\
\text { adults), was used*. A total of } 240 \text { individuals participated in the survey; about } \\
3 \% \text { of them were disqualified for incomplete questionnaires. The total sample } \\
\text { was thus composed of } 233 \text { adult respondents. Of these, } 51 \% \text { were men; } 19.4 \% \\
\text { of the respondents were between } 18 \text { and } 29 \text { years of age, } 36.1 \% \text { were between } \\
30 \text { and } 49 \text { years of age, } 34.5 \% \text { were between } 50 \text { and } 70 \text { years of age, and the } \\
\text { remaining } 10 \% \text { were over } 70 \text { years of age. Undergraduate or higher educated } \\
\text { respondents accounted for } 24.1 \% \text { of the sample, followed by respondents with } \\
\text { a high school education }(41.6 \% \text { ) or less }(34.3 \%) \text {. }\end{array}$ \\
\hline
\end{tabular}




\begin{tabular}{ll}
\hline $\begin{array}{l}\text { Further confirmation } \\
\text { of the scale validity } \\
\text { through a MTMM } \\
\text { analysis }\end{array}$ \\
\end{tabular}

Assessment of

Predictive Validity
Respondents were asked to answer questions by referring to general reshoring practices to relocate companies' activities in the home country. The 18-item CRS scale resulting from Study 2 was used. The items were measured on 7 point scales anchored by $1=$ "strongly disagree" and 7 = "strongly agree" as end-points, with intermediate points labeled (method 1). The average value of the items pertaining to each factor was used as an indicator of the six CRS dimensions for one method in the MTMM matrix analysis. We also added six direct measures (method 2) of each dimension of the consumer reshoring sentiment scale (Appendix A). The entire survey consisted of the 18 items from the CRS scale, the 6 items developed to measure the constructs with an alternative method, and demographic questions, for a total of 28 items.

To strengthen findings, we decided to collect data for reshoring cases in two different industries: the fashion industry (the reshored product was a shirt) and the electronics industry (the reshored product was an advanced food

processor). Thus, two versions of the questionnaire were developed where al the questions were the same; the only difference was the scenario detailing the reshored product (Appendix B). The survey consisted of the 18 items of the CRS scale, validation items, demographic and control questions, resulting in questionnaire with 41 items in total. CRS items were randomly mixed in the survey to ensure greater validity.

To test the cross-national applicability of the CRS scale, in Study 5 we

Cross-country validation of the CRS collected data in the U.S.. The same procedures for collecting data used in scale and empirical segmentation consumers and conducting surveys). A U.S. professor in management translated the
A new convenience quota sample of qualified respondents (i.e., Italian adult consumers) was obtained*. A total of 171 individuals participated in the survey; about $3 \%$ of them were disqualified for incomplete answers. The sample was thus composed of 166 respondents; $47 \%$ were men, $18.7 \%$ were between 18 and 29 years of age, $34.3 \%$ between 30 and 49 years of age, $37.3 \%$ between 50 and 70 years of age, and the remaining $9.7 \%$ were over 70 years old. Undergraduate or higher educated respondents accounted for $36.7 \%$ of the sample, followed by respondents with a high school education (53.6\%) or less $(9.6 \%)$

A new convenience quota sample of qualified respondents (i.e., Italian adult consumers) was used*. A total of 236 individuals participated in the survey; about $5 \%$ of them were disqualified for incomplete answers to the

questionnaire. The final sample was comprised of 224 respondents [ $50 \%$ were men, $19.2 \%$ were between 18 and 29 years of age, $41.5 \%$ between 30 and 49 years of age, $30.4 \%$ between 50 and 70 years of age, and the remaining $8.9 \%$ were over 70 years old. Undergraduate or higher educated respondents accounted for $35.3 \%$ of the sample, followed by respondents with a high school education $(39.7 \%)$ or less $(25 \%)]$. One hundred participants answered the questionnaire for the food processor, 124 for the shirt, As expected, respondents showed different levels of involvement $(t(222)=5.27 ; p<0.01)$ and product expertise $(t(222)=8.66 ; p<0.01)$ for the two products.

A total of 267 consumers participated in the survey**, about $7.5 \%$ of them were disqualified for incomplete answers to the questionnaire. The final sample was comprised of 247 respondents; $52.6 \%$ were women; $3.6 \%$ were between 20 and 29 years of age, $27.5 \%$ between 30 and 49 years of age, $60.3 \%$ between 50 and 70 years of age, and the remaining $8.5 \%$ were over 70 years old. Undergraduate or higher educated respondents accounted for $48.2 \%$ of the sample, followed by respondents with a high school education or some college or associate's degree $(49.8 \%)$ or less $(2 \%)$.

Italian-language questionnaire into English, and two different management professors then independently translated the questionnaire back into Italian to verify its accuracy. Using comparisons of the original and back-translated versions for semantic equivalence, two bilingual English-Italian speakers then refined the survey.

* Respondents in Studies 2, 3, and 4 were selected to reflect as much as possible the demographic characteristics of the Italian population according to Statistics Italy for 2012 (www.istat.it): gender: $49 \%$ male; age: $16 \%$ aged $18-29$ years, $36 \%$ aged 30-49 years, $32 \%$ aged $50-70$ years, and $16 \%$ aged 70 years and older; and level of education: $15.7 \%$ of undergraduate or higher educated respondents, $41.1 \%$ with a high school education, and $43.2 \%$ with a lower level of education.

** Respondents in Study 5 were selected to reflect as much as possible the demographic characteristics of the American population, according to the United States Census Bureau for 2012 (www.census.gov): gender: $51 \%$ female; age: $18.89 \%$ aged $20-29$ years, $36.14 \%$ aged $30-49$ years, $32.65 \%$ aged $50-70$ years, and $12.32 \%$ aged 70 years and older; and level of education: $26.73 \%$ of undergraduate or higher educated respondents, $55.69 \%$ with a high school education or some college or associate's degree, and $17.6 \%$ with a lower level of education. 
Table 2. Multiple positive beliefs about reshoring identified in the qualitative study

\begin{tabular}{|c|c|c|c|}
\hline & & Qualitative study & Literature review \\
\hline $\begin{array}{l}\text { CRS } \\
\text { dimensions }\end{array}$ & Definition & Example quote from the interviews & $\begin{array}{c}\text { Previous research addressing similar topics through } \\
\text { the firm-side perspective }\end{array}$ \\
\hline 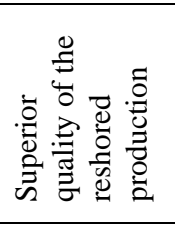 & $\begin{array}{l}\text { The beliefs of the home country consumer in developed } \\
\text { countries that reshored, home-made products are superior } \\
\text { (i.e., characterized by higher quality) to offshored products. }\end{array}$ & $\begin{array}{l}\text { "I am happy that some companies decide to reshore their } \\
\text { activities. I think that by operating abroad they failed to } \\
\text { replicate the same level of quality as that of Italian } \\
\text { production, and thus they have decided to relocate their } \\
\text { activities in Italy to increase the quality of their } \\
\text { products" (Female, } 39 \text { years old). }\end{array}$ & $\begin{array}{l}\text { Ancarani et al.,2015; Dachs \& Kinkel, } \\
\text { 2013; Fratocchi et al., 2014; Fratocchi et al., 2016; } \\
\text { Kinkel, 2012; 2014; Kinkel \& Maloca, 2009; Kinkel } \\
\text { \& Zanker, 2013; Knudsen \& Servais, 2007; Sirkin et } \\
\text { al. 2012. }\end{array}$ \\
\hline 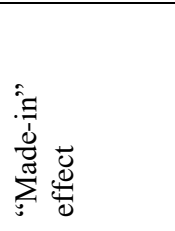 & $\begin{array}{l}\text { The consumers' positive beliefs about reshored products, } \\
\text { now made in the home-country. It is intended to refer to the } \\
\text { emotional nature of the "made-in" effect as experienced by } \\
\text { the individual when personally exposed to reshored } \\
\text { products, rather than the broad concept of the "made-in" } \\
\text { effect as manifest at the levels of the economy or firm. }\end{array}$ & $\begin{array}{l}\text { "I feel proud of the companies' reshoring decision } \\
\text { because in this way they recognized the value of the } \\
\text { "Made-in Italy" and contributed to preserve it. I } \\
\text { personally appreciate and defend "Made-in Italy" } \\
\text { because I am Italian!" (Female, } 57 \text { years old). }\end{array}$ & $\begin{array}{l}\text { Ancarani et al., 2015; Canham \& Hamilton, 2013; } \\
\text { Fratocchi et al. 2016; Martinez-Mora \& Merino, } 2014 .\end{array}$ \\
\hline 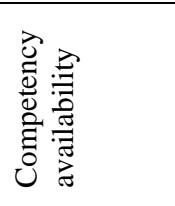 & $\begin{array}{l}\text { The beliefs of the home country consumer in developed } \\
\text { countries that domestic workers are superior (more skilled } \\
\text { and expert) to overseas workers and consequently they } \\
\text { believe that reshoring can have positive effects on } \\
\text { production. }\end{array}$ & $\begin{array}{l}\text { "Probably a growing number of companies are deciding } \\
\text { to reshore because the Italian workers are definitely } \\
\text { better than those whom they had found abroad, } \\
\text { especially in emerging countries!" (Male, } 45 \text { years old). }\end{array}$ & $\begin{array}{l}\text { Ancarani et al., 2015; Bharadwaj \& Roggeveen, 2008; } \\
\text { Canham \& Hamilton, 2013; Javalgi at al., 2001; Tate, } \\
\text { Ellram, Schoenherr, \& Petersen, 2014b; Thelen et al., } \\
2011 .\end{array}$ \\
\hline 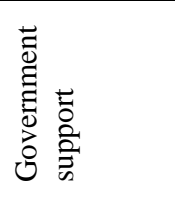 & $\begin{array}{l}\text { The beliefs of the home country consumer in developed } \\
\text { countries that the government should do more to favor } \\
\text { companies "coming back home" with their activities, in } \\
\text { order to fight against job losses and other negative effects in } \\
\text { the home-country due to offshoring. }\end{array}$ & $\begin{array}{l}\text { "These [reshoring] companies should be subsidized by } \\
\text { the Italian Government in order to encourage relocating } \\
\text { their activities in the home country" (Male, } 28 \text { years } \\
\text { old). }\end{array}$ & $\begin{array}{l}\text { Blinder, 2007; Ellram et al. 2013; Fratocchi et al., } \\
\text { 2016; Houseman, 2007; Sirkin et al., } 2012 \text {; Tafti, } \\
\text { 2005; Thelen et al., 2011. }\end{array}$ \\
\hline 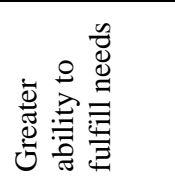 & $\begin{array}{l}\text { The beliefs of the home country consumers in developed } \\
\text { countries that reshored products are superior to offshored } \\
\text { ones in satisfying their needs. }\end{array}$ & $\begin{array}{l}\text { "Through reshoring we may have products that best meet } \\
\text { our needs as Italian consumers" (Female, } 61 \text { years old). }\end{array}$ & $\begin{array}{l}\text { Ellram et al. 2013; Fratocchi et al., 2014; Fratocchi et } \\
\text { al, 2016; Tate, Ellram, Bals, \& Hartmann, } 2009 .\end{array}$ \\
\hline 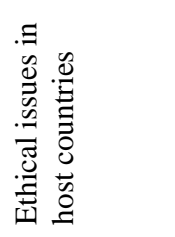 & $\begin{array}{l}\text { The ethical consumer beliefs about reshoring. In detail, } \\
\text { home country consumers in developed countries welcome } \\
\text { reshoring because these decisions are seen to stop the } \\
\text { exploitation of foreign workers, environmental pollution, } \\
\text { and human rights infringement in foreign emerging } \\
\text { countries. }\end{array}$ & $\begin{array}{l}\text { "I think that companies should act according not only to } \\
\text { law but also to moral obligations, and reshoring to Italy } \\
\text { can be considered a decision that ensures on the one } \\
\text { hand a greater compliance with the law, and on the other } \\
\text { hand greater respect for ethical and moral values." } \\
\text { (Female, } 46 \text { years old). }\end{array}$ & $\begin{array}{l}\text { This theme is not addressed by research adopting the } \\
\text { firm-side perspective }\end{array}$ \\
\hline
\end{tabular}


Table 3. Results of the CFA for the CRS scale (Study 2)

\begin{tabular}{|c|c|c|c|c|}
\hline & $\begin{array}{c}\text { Std. factor loading } \\
\text { (t-value) }\end{array}$ & AVE & CR & $\begin{array}{c}\text { Mean score } \\
\text { (s.d.) }\end{array}$ \\
\hline Quality superiority of the reshored production & & & & $4.92(1.54)$ \\
\hline $\begin{array}{l}\text { The quality of the reshored products is higher compared to the quality of } \\
\text { products made abroad. }\end{array}$ & $0.92 * * *(17.96)$ & & & \\
\hline $\begin{array}{l}\text { The quality of the reshored products is better than that of products made } \\
\text { abroad. }\end{array}$ & $0.96 * * *(19.23)$ & 0.76 & 0.90 & \\
\hline $\begin{array}{l}\text { The quality of the reshored products is definitely not comparable (as it's } \\
\text { better) to that of products made abroad. }\end{array}$ & $0.75^{* * * *(13.14)}$ & & & \\
\hline Greater ability to fulfil needs & & & & $4.29(1.64)$ \\
\hline $\begin{array}{l}\text { The reshored products are more able to meet our needs compared to the } \\
\text { products the company made abroad before. }\end{array}$ & $0.90 * * *(16.87)$ & & & \\
\hline $\begin{array}{l}\text { The reshored products are more in line with our cultural characteristics than } \\
\text { products made abroad. }\end{array}$ & $0.87 * * *(16.23)$ & 0.72 & 0.88 & \\
\hline $\begin{array}{l}\text { The offshored products were less able to satisfy our needs compared to the } \\
\text { reshored ones. }\end{array}$ & $0.78 * * *(13.59)$ & & & \\
\hline Government support & & & & $5.46(1.67)$ \\
\hline Companies that reshored should be supported by the Government. & $0.94 * * *(18.51)$ & & & \\
\hline $\begin{array}{l}\text { The Government should support companies who decide to reshore even if } \\
\text { they face higher costs. }\end{array}$ & $0.84 * * *(15.41)$ & 0.79 & 0.92 & \\
\hline $\begin{array}{l}\text { The Government should support companies who decide to reshore thus } \\
\text { promoting the economic welfare of the country. }\end{array}$ & $0.89 * * *(17.09)$ & & & \\
\hline
\end{tabular}

\begin{tabular}{|c|c|c|c|c|c|}
\hline \multicolumn{3}{|l|}{ "Made-in" effect } & & & $5.71(1.35)$ \\
\hline \multicolumn{6}{|l|}{ I consider the reshored products more favorably now that use the label } \\
\hline $\begin{array}{l}\text { "Made in Italy", than before when labels of products indicated made in } \\
\text { foreign countries. }\end{array}$ & \multicolumn{2}{|c|}{$0.80 * * *(14.34)$} & & & \\
\hline $\begin{array}{l}\text { Now I am proud to see "Made in Italy" on products that before were made } \\
\text { abroad. }\end{array}$ & \multicolumn{2}{|c|}{$0.89 * * *(17.04)$} & 0.69 & 0.87 & \\
\hline $\begin{array}{l}\text { Now I am happy to see the label "Made in Italy" on products that before } \\
\text { were made abroad. }\end{array}$ & \multicolumn{2}{|c|}{$0.92 * * *(17.84)$} & & & \\
\hline \multicolumn{3}{|l|}{ Competency availability } & & & $4.74(1.63)$ \\
\hline \multirow{2}{*}{$\begin{array}{l}\text { I welcome the company reshoring decision because I am convinced that } \\
\text { Italian workers have better skills than workers of foreign countries. } \\
\text { I evaluate favorably the company reshoring decision because I am convinced } \\
\text { that the Italian workers have higher competences than workers of foreign } \\
\text { countries. }\end{array}$} & \multicolumn{2}{|c|}{$0.91 * * *(17.68)$} & & & \\
\hline & \multicolumn{2}{|c|}{$0.94 * * *(18.61)$} & 0.76 & 0.90 & \\
\hline $\begin{array}{l}\text { I consider positively the company reshoring decision because I believe that } \\
\text { foreign countries don't have workers with adequate skills and competences. }\end{array}$ & \multicolumn{2}{|c|}{$0.76^{* * * *}(13.47)$} & & & \\
\hline \multicolumn{3}{|l|}{ Ethical issues in host countries } & & & $5.81(1.33)$ \\
\hline \multicolumn{3}{|l|}{$\begin{array}{l}\text { I welcome the reshoring decision because this means that the company stops } \\
\text { exploiting workers of foreign countries, who often work in conditions worse } \\
\text { than those guaranteed in our country. }\end{array}$} & & & \\
\hline $\begin{array}{l}\text { I welcome the reshoring decision because this means that the company stops } \\
\text { exploiting environmental regulations less stringent than those of our country, } \\
\text { which often results in greater pollution. }\end{array}$ & \multicolumn{2}{|c|}{$0.81 * * *(14.26)$} & 0.69 & 0.87 & \\
\hline $\begin{array}{l}\text { I welcome the reshoring decision because this means that the company stops } \\
\text { exploiting regulations of foreign countries disrespectful of human rights. }\end{array}$ & \multicolumn{2}{|c|}{$0.90 * * *(16.66)$} & & & \\
\hline \multicolumn{6}{|c|}{ Inter-correlations among dimensions (std. error) } \\
\hline 1 & 2 & 3 & 4 & 5 & 6 \\
\hline 1. Quality superiority of the reshored production & & & & & \\
\hline 2. Greater ability to fulfil needs & 1.00 & & & & \\
\hline 3. Government support & $\begin{array}{l}0.44 * * * \\
(0.06)\end{array}$ & 1.00 & & & \\
\hline 4. "Made-in" effect & $\begin{array}{l}0.58 * * * \\
(0.05)\end{array}$ & $\begin{array}{l}0.46^{* * * *} \\
(0.06)\end{array}$ & 1.00 & & \\
\hline 5. Competency availability & $\begin{array}{l}0.59 * * * \\
(0.05)\end{array}$ & $\begin{array}{l}0.23 * * \\
(0.07)\end{array}$ & $\begin{array}{l}0.55 * * * \\
(0.05)\end{array}$ & 1.00 & \\
\hline 6. Ethical issues in host countries & $\begin{array}{l}0.31 * * * \\
(0.07)\end{array}$ & $\begin{array}{l}0.35^{* * * *} \\
(0.06)\end{array}$ & $\begin{array}{l}0.48^{* * * *} \\
(0.06)\end{array}$ & $\begin{array}{l}0.31 * * * \\
(0.07)\end{array}$ & 1.00 \\
\hline
\end{tabular}

** if $\mathrm{p}<0.01, * * *$ if $\mathrm{p}<0.001 .{ }^{\mathrm{a}} \mathrm{All}$ the items of the scale range from a minimum of 1 to a maximum of $7 . \mathrm{N}=233$. 
Table 4. Results of the second-order CFA for the CRS scale (Study 2)

\begin{tabular}{|c|c|c|c|c|c|}
\hline \multicolumn{3}{|c|}{ Second-order factor } & \multicolumn{2}{|l|}{ First-order factors } & \multirow[b]{2}{*}{$t$-value } \\
\hline & $\begin{array}{c}\text { Std. } \\
\text { factor } \\
\text { loading }\end{array}$ & t-value & & $\begin{array}{c}\text { Std. } \\
\text { factor } \\
\text { loading }\end{array}$ & \\
\hline & $0.69^{* * * *}$ & 10.23 & Quality superiority of the reshored production & & \\
\hline & & & $\begin{array}{l}\text { The quality of the reshored products is higher compared to the } \\
\text { quality of products made abroad. }\end{array}$ & 0.92 & -- \\
\hline & & & $\begin{array}{l}\text { The quality of the reshored products is better than that of } \\
\text { products made abroad. }\end{array}$ & $0.96^{* * *}$ & 23.76 \\
\hline & & & $\begin{array}{l}\text { The quality of the reshored products is definitely not } \\
\text { comparable (as it's better) to that of products made abroad. }\end{array}$ & $0.75^{* * *}$ & 14.85 \\
\hline & $0.77 * * *$ & 11.19 & Greater ability to fulfil needs & & \\
\hline & & & $\begin{array}{l}\text { The reshored products are more able to meet our needs } \\
\text { compared to the products the company made abroad before. }\end{array}$ & 0.90 & -- \\
\hline & & & $\begin{array}{l}\text { The reshored products are more in line with our cultural } \\
\text { characteristics than products made abroad. }\end{array}$ & $0.87 * * *$ & 17.21 \\
\hline & & & $\begin{array}{l}\text { The offshored products were less able to satisfy our needs } \\
\text { compared to the reshored ones. }\end{array}$ & $0.78 * * *$ & 14.48 \\
\hline & $0.50^{* * * *}$ & 7.14 & Government support & & \\
\hline & & & $\begin{array}{l}\text { Companies that reshored should be supported by the } \\
\text { Government. }\end{array}$ & 0.94 & -- \\
\hline & & & $\begin{array}{l}\text { The Government should support companies who decide to } \\
\text { reshore even if they face higher costs. }\end{array}$ & $0.84 * * *$ & 18.31 \\
\hline & & & $\begin{array}{l}\text { The Government should support companies who decide to } \\
\text { reshore thus promoting the economic welfare of the country. }\end{array}$ & $0.89 * * *$ & 20.86 \\
\hline & $0.80^{* * * *}$ & 10.70 & "Made-in" effect & & \\
\hline \multirow{11}{*}{$\begin{array}{l}\text { Consumer } \\
\text { Reshoring } \\
\text { Sentiment }\end{array}$} & & & $\begin{array}{l}\text { I consider the reshored products more favorably now that use } \\
\text { the label "Made in Italy", than before when they brought back } \\
\text { labels of products indicated made in foreign countries. }\end{array}$ & 0.80 & -- \\
\hline & & & $\begin{array}{l}\text { Now I am proud to see "Made in Italy" on products that before } \\
\text { were made abroad. }\end{array}$ & $0.90 * * *$ & 15.72 \\
\hline & & & $\begin{array}{l}\text { Now I am happy to see the label "Made in Italy" on products } \\
\text { that before were made abroad. }\end{array}$ & $0.92 * * *$ & 16.09 \\
\hline & $0.71 * * *$ & 10.45 & Competency availability & & \\
\hline & & & $\begin{array}{l}\text { I welcome the company reshoring decision because I am } \\
\text { convinced that Italian workers have better skills than workers of } \\
\text { foreign countries. }\end{array}$ & 0.92 & -- \\
\hline & & & $\begin{array}{l}\text { I evaluate favorably the company reshoring decision because I } \\
\text { am convinced that Italian workers have higher competences } \\
\text { than workers of foreign countries. }\end{array}$ & $0.94 * * *$ & 21.95 \\
\hline & & & $\begin{array}{l}\text { I consider positively the company reshoring decision because I } \\
\text { believe that foreign countries don't have workers with adequate } \\
\text { skills and competences. }\end{array}$ & $0.76^{* * *}$ & 15.20 \\
\hline & $0.51 * * *$ & 6.73 & Ethical issues in host countries & & \\
\hline & & & $\begin{array}{l}\text { I welcome the reshoring decision because this means that the } \\
\text { company stops exploiting workers of foreign countries, who } \\
\text { often work in conditions worse than those guaranteed in our } \\
\text { country. }\end{array}$ & 0.80 & -- \\
\hline & & & $\begin{array}{l}\text { I welcome the reshoring decision because this means that the } \\
\text { company stops exploiting environmental regulations less } \\
\text { stringent than those of our country, which often results in } \\
\text { greater pollution. }\end{array}$ & $0.81 * * *$ & 13.27 \\
\hline & & & $\begin{array}{l}\text { I welcome the reshoring decision because this means that the } \\
\text { company stops exploiting regulations of foreign countries } \\
\text { disrespectful of human rights. }\end{array}$ & $0.90 * * *$ & 14.32 \\
\hline
\end{tabular}


Table 5. MTMM matrix standardized factor loadings and correlations of six traits using two methods for measuring CRS (Study 3)

\begin{tabular}{|c|c|c|c|c|c|c|c|c|c|}
\hline \multirow[b]{2}{*}{ Items } & \multirow[b]{2}{*}{$Q$} & \multicolumn{4}{|c|}{ Traits (std. loading) } & \multicolumn{4}{|c|}{$\begin{array}{c}\text { Methods } \\
\text { (std. loading) }\end{array}$} \\
\hline & & $N$ & $G S$ & $M I$ & $C A$ & E & Method 1 & Method 2 & $\begin{array}{c}\text { Error } \\
\text { variance }\end{array}$ \\
\hline Q1 & $0.93 * * *$ & & & & & & $0.37 * * *$ & & 0.01 \\
\hline Q2 & $0.64 * * *$ & & & & & & & $0.77 * * *$ & 0.16 \\
\hline N1 & & $0.87 * * *$ & & & & & $0.44 * * *$ & & 0.12 \\
\hline $\mathrm{N} 2$ & & $0.87 * * *$ & & & & & & $0.29 * * *$ & 0.14 \\
\hline GS1 & & & $0.96^{* * * *}$ & & & & $0.10^{* * * *}$ & & 0.50 \\
\hline GS2 & & & $0.98 * * *$ & & & & & $-0.10^{* * * *}$ & 0.02 \\
\hline MI1 & & & & $0.89 * * *$ & & & $0.35^{* * * *}$ & & 0.01 \\
\hline MI2 & & & & $0.93 * * *$ & & & & $0.10 * *$ & 0.45 \\
\hline CA1 & & & & & $0.85^{* * *}$ & & $0.33 * * *$ & & 0.11 \\
\hline CA2 & & & & & $0.99 * * *$ & & & 0.07 & 0.19 \\
\hline E1 & & & & & & $0.74 * * *$ & $0.67 * * *$ & & -0.01 \\
\hline E2 & & & & & & $0.64 * * *$ & & $0.44 * * *$ & 1.32 \\
\hline \multirow[t]{2}{*}{$\begin{array}{l}\text { Squared trait } \\
\text { communality of } \\
\text { the average } \\
\text { factor loadings }\end{array}$} & $62 \%$ & $76 \%$ & $94 \%$ & $83 \%$ & $85 \%$ & $48 \%$ & & & \\
\hline & & Ave & cage trait $\mathrm{v}$ & riance $=51$ & $.35 \%$ & & $\begin{array}{c}\text { Average } \\
\text { variance }=\end{array}$ & $\begin{array}{l}\text { method } \\
=31.51 \%\end{array}$ & $\begin{array}{c}\text { Average } \\
\text { random error } \\
\text { variance = } \\
17.14 \%\end{array}$ \\
\hline \multicolumn{10}{|c|}{ Correlation (std. error) } \\
\hline & & $Q$ & $N$ & $G S$ & $M I$ & $C A$ & $E$ & Method 1 & Method 2 \\
\hline & & 1.00 & & & & & & & \\
\hline & $\mathrm{N}$ & $\begin{array}{l}0.87 * * * \\
(0.02)\end{array}$ & 1.00 & & & & & & \\
\hline & GS & $\begin{array}{l}0.48^{* * * *} \\
(0.06)\end{array}$ & $\begin{array}{l}0.39 * * * \\
(0.07)\end{array}$ & 1.00 & & & & & \\
\hline & MI & $\begin{array}{l}0.75^{* * * *} \\
(0.04)\end{array}$ & $\begin{array}{l}0.75^{* * * *} \\
(0.04)\end{array}$ & $\begin{array}{l}0.84 * * * \\
(0.03)\end{array}$ & 1.00 & & & & \\
\hline & $\mathrm{CA}$ & $\begin{array}{l}0.90 * * * \\
(0.02)\end{array}$ & $\begin{array}{l}0.92 * * * \\
(0.02)\end{array}$ & $\begin{array}{l}0.40 * * * \\
(0.07)\end{array}$ & $\begin{array}{l}0.74 * * * \\
(0.04)\end{array}$ & 1.00 & & & \\
\hline & E & $\begin{array}{l}0.86^{* * * *} \\
(0.03)\end{array}$ & $\begin{array}{l}0.90 * * * \\
(0.03)\end{array}$ & $\begin{array}{l}0.67 * * * \\
(0.06)\end{array}$ & $\begin{array}{l}0.92 * * * \\
(0.03)\end{array}$ & $\begin{array}{l}0.93 * * * \\
(0.03)\end{array}$ & 1.00 & & \\
\hline & Method 1 & & & & & & & 1.00 & \\
\hline & Method 2 & & & & & & & $\begin{array}{l}0.65 * * * \\
(0.15)\end{array}$ & 1.00 \\
\hline
\end{tabular}

$\mathrm{Q}=$ Quality superiority of the reshored production; $\mathrm{N}=$ Greater ability to fulfil needs; GS = Government support; $\mathrm{MI}=$ "Made-in" effect; $\mathrm{CA}=$ Competency availability; $\mathrm{E}=$ Ethical issues in host countries; $* *$ if $\mathrm{p}<0.01$, *** if $\mathrm{p}<0.001 . \mathrm{N}=$ 166. 
Table 6. Results of the causal models considering the dependent variables and the CRS dimensions (Study 4)

\begin{tabular}{lllll}
\hline & $\begin{array}{l}\text { Attitude toward } \\
\text { the company }\end{array}$ & $\begin{array}{l}\text { Positive word of } \\
\text { mouth }\end{array}$ & Intention to buy & VIF \\
\hline CRS dimensions & \multicolumn{4}{c}{ Std. coefficients (t-value) } \\
\hline $\begin{array}{l}\text { Quality superiority of the reshored } \\
\text { production }\end{array}$ & $0.60^{* * *}(5.80)$ & $0.15^{\dagger}(1.64)$ & $0.15^{\dagger}(1.68)$ & 4.34 \\
Greater ability to fulfil needs & n.s. & n.s. & $0.12^{\dagger}(1.66)$ & 3.34 \\
Government support & n.s. & $0.31^{* * *}(3.58)$ & $0.52^{* * *}(5.84)$ & 4.19 \\
"Made-in" effect & $0.21^{*}(2.27)$ & n.s. & n.s. & 3.62 \\
Competency availability & n.s. & $0.50^{* * *}(5.68)$ & n.s. & 3.49 \\
Ethical issues in host countries & $0.15^{*}(2.27)$ & $0.15^{*}(2.28)$ & $0.17 * *(2.61)$ & 2.35 \\
Control variable (type of product) & $-0.26^{* * *}(-5.27)$ & n.s. & n.s. & 1.41 \\
\hline$\chi^{2} /$ df; $p$ & $742.99 / 204 ;$ & $857.10 / 204 ;$ & $789.74 / 204 ;$ & \\
CFI & $p=0.00$ & $p=0.00$ & $p=0.00$ & \\
NNFI & 0.95 & 0.95 & 0.96 & \\
RMSEA & 0.96 & 0.96 & 0.96 & 0.08 \\
SRMR & 0.08 & 0.08 & 0.05 & \\
\hline
\end{tabular}

i if $\mathrm{p}<0.10, *$ if $\mathrm{p}<0.05, * *$ if $\mathrm{p}<0.01, * * *$ if $\mathrm{p}<0.001 ;$ n.s. $=$ non-significant relationship. $\mathrm{N}=224$. 
Table 7. Segments description (Study 5)

\begin{tabular}{|c|c|c|c|c|c|c|c|c|c|}
\hline \multirow[b]{2}{*}{ Segments } & \multirow{2}{*}{$\begin{array}{l}\text { Size } \\
\text { (\% of the total sample) }\end{array}$} & \multicolumn{3}{|c|}{$\begin{array}{l}\text { Demographic characteristics } \\
\text { (frequencies) }\end{array}$} & \multicolumn{2}{|c|}{$\begin{array}{c}\text { Clustering variables } \\
\text { Mean values (std. deviation) }\end{array}$} & \multicolumn{3}{|c|}{$\begin{array}{c}\text { Relevant responses } \\
\text { Mean values (std. deviation) }\end{array}$} \\
\hline & & Age & Gender & Level of education & CRS & Ethnocentrism & Attitude & $\begin{array}{l}\text { Word of } \\
\text { mouth }\end{array}$ & $\begin{array}{l}\text { Intention to } \\
\text { buy }\end{array}$ \\
\hline $\begin{array}{l}\text { Reshoring } \\
\text { neutrals }\end{array}$ & $\begin{array}{l}37 \\
(15.0 \%)\end{array}$ & $\begin{array}{l}20-29=2 \\
30-49=14 \\
50-70 \text { and older }=21\end{array}$ & $\begin{array}{l}M=20 \\
F=17\end{array}$ & $\begin{array}{l}\text { Undergraduate }=19 \\
\text { High } \text { school }=17 \\
\text { Less }=1\end{array}$ & $3.96(0.71)$ & $2.68(0.61)$ & $4.75(0.87)$ & $4.10(1.28)$ & $4.23(0.98)$ \\
\hline $\begin{array}{l}\text { Reshoring } \\
\text { advocates }\end{array}$ & $\begin{array}{l}44 \\
(17.8 \%)\end{array}$ & $\begin{array}{l}20-29=3 \\
30-49=9 \\
50-70 \text { and older }=32\end{array}$ & $\begin{array}{l}M=22 \\
F=22\end{array}$ & $\begin{array}{l}\text { Undergraduate }=26 \\
\text { High school }=18 \\
\text { Less }=0\end{array}$ & $5.80(0.35)$ & $3.61(0.68)$ & $5.80(1.20)$ & $5.36(1.18)$ & $5.90(0.86)$ \\
\hline $\begin{array}{l}\text { Ethnocentric } \\
\text { reshoring } \\
\text { neutrals }\end{array}$ & $\begin{array}{l}66 \\
(26.7 \%)\end{array}$ & $\begin{array}{l}20-29=3 \\
30-49=22 \\
50-70 \text { and older }=41\end{array}$ & $\begin{array}{l}M=36 \\
F=30\end{array}$ & $\begin{array}{l}\text { Undergraduate }=30 \\
\text { High school }=35 \\
\text { Less }=1\end{array}$ & $4.53(0.48)$ & $4.22(0.46)$ & $4.91(1.01)$ & $4.39(0.98)$ & $4.69(0.84)$ \\
\hline $\begin{array}{l}\text { Ethnocentric } \\
\text { reshoring } \\
\text { advocates }\end{array}$ & $\begin{array}{l}100 \\
(40.5 \%)\end{array}$ & $\begin{array}{l}20-29=1 \\
30-49=23 \\
50-70 \text { and older }=76\end{array}$ & $\begin{array}{l}\mathrm{M}=52 \\
\mathrm{~F}=48\end{array}$ & $\begin{array}{l}\text { Undergraduate }=44 \\
\text { High } \mathrm{school}=53 \\
\text { Less }=3\end{array}$ & $5.93(0.58)$ & $5.70(0.62)$ & $5.85(1.31)$ & $5.74(1.04)$ & $6.04(0.93)$ \\
\hline
\end{tabular}


Table 8. Planned comparisons to evaluate the four segment's differences (Study 5)

\begin{tabular}{|c|c|c|c|c|}
\hline \multirow[t]{2}{*}{ Segments } & & $\begin{array}{l}\text { Attitude toward the } \\
\text { company }\end{array}$ & Word of mouth & Intention to buy \\
\hline & & \multicolumn{3}{|c|}{$t(\mathrm{df}) ; p$} \\
\hline \multirow{3}{*}{$\begin{array}{l}\text { Ethnocentric } \\
\text { reshoring } \\
\text { advocates }\end{array}$} & Reshoring advocates & $0.25(142) ; p=0.80$ & $1.90(142) ; p=0.06$ & $0.84(142) ; p=0.40$ \\
\hline & $\begin{array}{l}\text { Ethnocentric } \\
\text { reshoring neutrals }\end{array}$ & $4.95(164) ; p<0.001$ & $8.31(164) ; p<0.001$ & $9.52(164) ; p<0.001$ \\
\hline & Reshoring neutrals & $4.75(135) ; p<0.001$ & $7.66(135) ; p<0.001$ & $9.98(135) ; p<0.001$ \\
\hline \multirow{2}{*}{$\begin{array}{l}\text { Reshoring } \\
\text { advocates }\end{array}$} & $\begin{array}{l}\text { Ethnocentric } \\
\text { reshoring neutrals }\end{array}$ & $4.18(108) ; p<0.001$ & $4.69(108) ; p<0.001$ & $7.36(108) ; p<0.001$ \\
\hline & Reshoring neutrals & $4.43(79) ; p<0.001$ & $4.63(79) ; p<0.001$ & $8.20(79) ; p<0.001$ \\
\hline $\begin{array}{l}\text { Ethnocentric } \\
\text { reshoring } \\
\text { neutrals }\end{array}$ & Reshoring neutrals & $0.81(101) ; p=0.42$ & $1.31(101) ; p=0.19$ & $2.52(101) ; p=0.02$ \\
\hline
\end{tabular}

$\mathrm{N}=247$ 